\title{
Field Crop Responses and Management Strategies to Mitigate Soil Salinity in Modern Agriculture: A Review
}

\author{
Hiba M. Alkharabsheh ${ }^{1}$, Mahmoud F. Seleiman ${ }^{2,3, *(\mathbb{D}, \text { Omar A. Hewedy }}{ }^{4,5}{ }^{(}$, Martin L. Battaglia ${ }^{6}(\mathbb{D}$, \\ Rewaa S. Jalal ${ }^{7}$, Bushra A. Alhammad ${ }^{8}$, Calogero Schillaci ${ }^{9}$, , Nawab Ali ${ }^{10}$ and Abdullah Al-Doss ${ }^{2}(\mathbb{D}$
}

check for

updates

Citation: Alkharabsheh, H.M.

Seleiman, M.F.; Hewedy, O.A.;

Battaglia, M.L.; Jalal, R.S.; Alhammad,

B.A.; Schillaci, C.; Ali, N.; Al-Doss, A.

Field Crop Responses and Management Strategies to Mitigate Soil Salinity in

Modern Agriculture: A Review.

Agronomy 2021, 11, 2299. https://

doi.org/10.3390/agronomy11112299

Academic Editor: Anna Tedeschi

Received: 22 October 2021

Accepted: 11 November 2021

Published: 13 November 2021

Publisher's Note: MDPI stays neutral with regard to jurisdictional claims in published maps and institutional affiliations.

Copyright: (c) 2021 by the authors. Licensee MDPI, Basel, Switzerland. This article is an open access article distributed under the terms and conditions of the Creative Commons Attribution (CC BY) license (https:/ / creativecommons.org/licenses/by/ $4.0 /)$.
1 Department of Water Resources and Environmental Management, Faculty of Agricultural Technology, Al Balqa Applied University, Salt 19117, Jordan; Drhibakh@bau.edu.jo

2 Plant Production Department, College of Food and Agriculture Sciences, King Saud University, P.O. Box 2460, Riyadh 11451, Saudi Arabia; aaldoss@ksu.edu.sa

3 Department of Crop Sciences, Faculty of Agriculture, Menoufia University, Shibin El-Kom 32514, Egypt

4 Department of Plant Agriculture, University of Guelph, 50 Stone Road East, Guelph, ON N1G 2W1, Canada; ohewedy@uoguelph.ca

5 Department of Genetics, Faculty of Agriculture, Menoufia University, Shibin El-Kom 32514, Egypt

6 Department of Animal Sciences, Cornell University, Ithaca, NY 14850, USA; mlb487@cornell.edu

7 Department of Biology, College of Sciences, University of Jeddah, Jeddah 21493, Saudi Arabia; rsjalal@uj.edu.sa

8 Biology Department, College of Science and Humanity Studies, Prince Sattam Bin Abdulaziz University, Al Kharj Box 292, Riyadh 11942, Saudi Arabia; b.alhamad@psau.edu.sa

9 Department of Agricultural and Environmental Sciences, University of Milan, via Celoria 2, 20122 Milan, Italy; calogero.schillaci@unimi.it

10 Agriculture and Biological Engineering, Institute of Food and Agriculture Science, University of Florida, Gainesville, FL 32611, USA; nawabali@ufl.edu

* Correspondence: mseleiman@ksu.edu.sa or mahmoud.seleiman@agr.menofia.edu.eg

Abstract: The productivity of cereal crops under salt stress limits sustainable food production and food security. Barley followed by sorghum better adapts to salinity stress, while wheat and maize are moderately adapted. However, rice is a salt-sensitive crop, and its growth and grain yield are significantly impacted by salinity stress. High soil salinity can reduce water uptake, create osmotic stress in plants and, consequently, oxidative stress. Crops have evolved different tolerance mechanisms, particularly cereals, to mitigate the stressful conditions, i.e., effluxing excessive sodium $\left(\mathrm{Na}^{+}\right)$or compartmentalizing $\mathrm{Na}^{+}$to vacuoles. Likewise, plants activate an antioxidant defense system to detoxify apoplastic cell wall acidification and reactive oxygen species (ROS). Understanding the response of field crops to salinity stress, including their resistance mechanisms, can help breed adapted varieties with high productivity under unfavourable environmental factors. In contrast, the primary stages of seed germination are more critical to osmotic stress than the vegetative stages. However, salinity stress at the reproductive stage can also decrease crop productivity. Biotechnology approaches are being used to accelerate the development of salt-adapted crops. In addition, hormones and osmolytes application can mitigate the toxicity impact of salts in cereal crops. Therefore, we review the salinity on cereal crops physiology and production, the management strategies to cope with the harmful negative effect on cereal crops physiology and production of salt stress.

Keywords: cereal; salinity; mitigation effects; mechanisms; modern agriculture

\section{Introduction}

This review aims to focus on how to address the issue of the impact of soil salinity stress on cereal crops growth and yields, the mechanisms of salt stress tolerance, and the management strategies to mitigate these effects. Cereals fulfil more than $50 \%$ of the human energy and protein requirement [1]. Among cereals, maize (Zea mays L.), rice (Oryza sativa L.), bread wheat (Triticum aestivum L.), barley (Hordeum vulgare L.) and 
sorghum (Sorghum bicolour (L.) Moench) are the most widely cultivated in the world. Wheat, rice, and maize provide about 48 and $42 \%$ of the total calories and protein, respectively [1,2]. Besides their nutritious value, among other uses, there has been an increased interest in the potential use of residues from maize and wheat in the bioenergy industry and wheat as a cover crop $[3,4]$. Globally, about $66 \%$ of the cultivated areas are cultivated with cereal crops [2] since they are adapted to an ample range of climatic conditions. For instance, the temperate climate is suitable for wheat and barley cultivation, while maize is cultivated dominantly in tropical regions [2,5]. In rice, it is mainly cultivated in wet tropic regions of the world, while sorghum is mainly cultivated in dry areas. However, their cultivation in temperate regions is also suitable [6].

As the world's population increases, it is estimated that food production will need to increase between $87 \%$ and $100 \%$ by 2050 to meet its nutritional needs. Expectations are that a considerable portion of this increase will be provided by increases in the production of cereal crops [7,8]. Different stresses such as heat, salinity, drought, and heavy metal stress severely disturb crop production [9-13]. Among these, salinity stress is perhaps the most critical and pervasive global abiotic stress, affecting $20 \%$ of the world's total cultivated area and causing about $20 \%$ yield losses [14,15]. On a global scale, soil salinization is accelerated due to climate change, intensive farming, poor cultivated land drainage, and contaminated or low-quality irrigation water $[6,14,16]$. Cereals are an essential food source to the world population, with a global production of 2719 million tones $[8,17]$. At present, however, complete global food security has not been achieved, with estimations of more than 800 million people still facing chronic hunger [18]. The detrimental impacts of climate change and different biotic and abiotic stresses on crop productivity, alongside the fast-growing population, and arable land degradation, increase the current global food shortage [19-21]. Thus, without a significant improvement in cereals production, the gap between production and demand will increase.

Salinity can significantly decrease crops' growth and yield due to the osmotic, ionic and oxidative stresses [22]. High sodium $\left(\mathrm{Na}^{+}\right)$in the soil can cause nutrient deficiencies such as potassium $\left(\mathrm{K}^{+}\right)$by decreasing the $\mathrm{K}^{+}$uptake and increasing its exclusion from the cells [23]. Salt stress can also damage cellular homeostasis, denature protein and nucleic acids, induce lipid peroxidation, and increase reactive oxygen species (ROS) $[15,24,25]$. To reduce these adverse effects, plants should utilize adaptive strategies such as reducing the $\mathrm{Na}^{+}$ion uptake and maintaining the internal osmotic balance, enhancing the accumulation of osmolytes, and scavenging ROS antioxidant defense system [25].

Management approaches are commonly proposed to mitigate the salinity conditions, including saline-resistant genotypes, nanoparticles application, hormones, and osmoprotectants. This review aims to summarize the question; how the impact of salinity stress on cereal crops growth and yield, the mechanisms of salt stress tolerance, and the management strategies to mitigate these effects.

\section{Seed Germination, Vegetative Growth, Yield and Yield Quality under Salt Stress Condition}

Unfavourable environmental conditions adversely affect plants' physiological functions, decrease crop yields and quality (Figure 1). Reactive oxygen species generation can induce oxidative stress in plants, determine a cascade of plant responses that negatively affect plant photosynthesis, $\mathrm{CO}_{2}$ uptake, and relative water content (RWC) and increase plant photorespiration pollen sterility, lipid, and electrolyte leakage. Therefore, the whole plant growth, crop yield and quality are negatively affected. The salt sensitivity of plants varies during their lifecycle, but the seedling and reproductive stages are the most sensitive. In that case, the impacts on crop yields and quality can be drastic, as the reproductive stage is the most susceptible for crop yield and grain quality in cereal crops. 


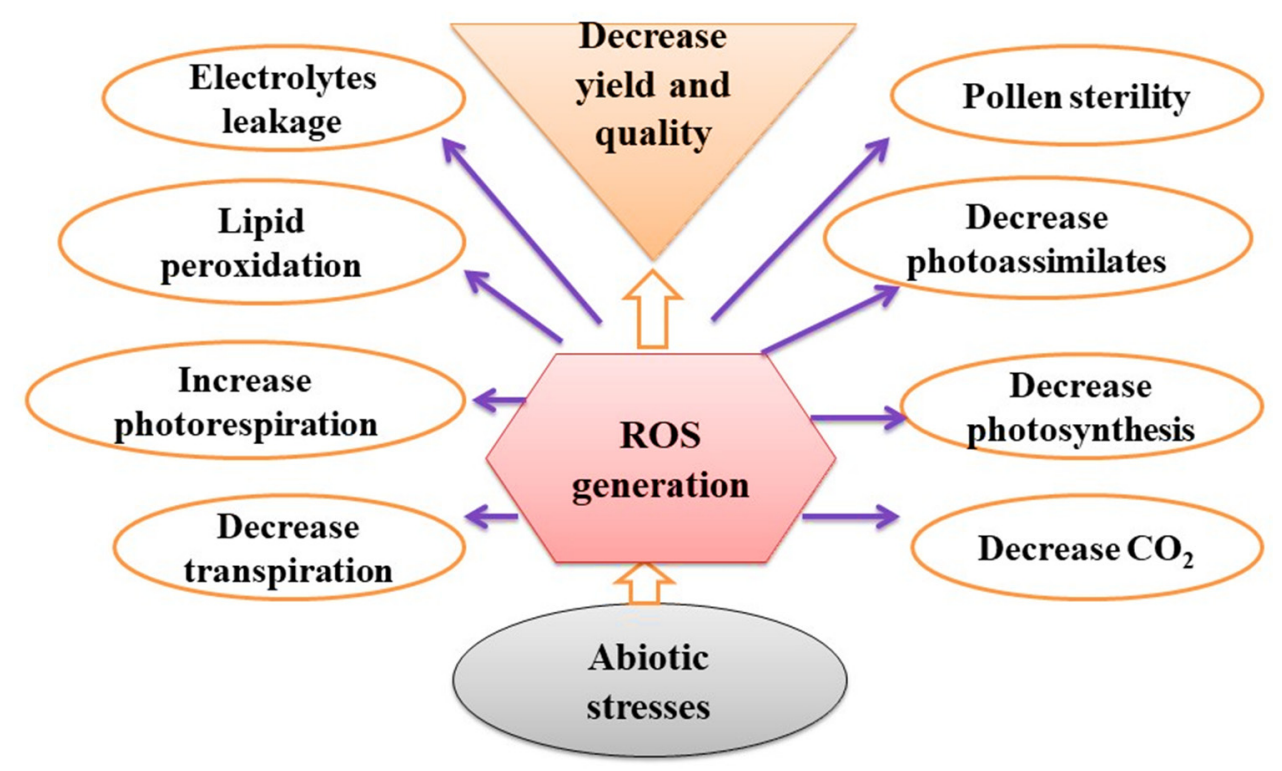

Figure 1. The effect of abiotic stresses on plant's physiological traits, yield and quality.

When the electrical conductivity of a soil extract from a saturated paste (ECe) is higher than $4 \mathrm{dS} \mathrm{m}^{-1}$, the soil is considered saline soil [26]. In most cases, sodium $\left(\mathrm{Na}^{+}\right)$, chloride $\left(\mathrm{Cl}^{-}\right)$, sulphate $\left(\mathrm{SO}_{4}{ }^{2-}\right)$, bicarbonate $\left(\mathrm{HCO}_{3}{ }^{-}\right)$, potassium $\left(\mathrm{K}^{+}\right)$, magnesium $\left(\mathrm{Mg}^{2+}\right)$, and nitrate $\left(\mathrm{NO}_{3}{ }^{-}\right)$ions are presented in the soil solution. A high concentration of $\mathrm{Na}^{+}$ions in the soil solution can create a difference in favour of the monovalent cations over the divalent cations in the soil (i.e., ratio monovalent: divalent cations).

Other factors, i.e., water shortage, rainfall limitations, and high evapotranspiration, induced soil salinity in various regions of the globe $[27,28]$. A high concentration of salts in the soil solution can negatively affect the uptake of water and essential nutrients, reduce plant growth and development, and alter the physiochemical processes (Figure 2) [6,28,29]. The first effect of salinity stress on plants is osmotic, while the second effect is ionic. As a result, plants close their stomata, decrease transpiration rate, and lose turgor pressure, which halts root expansion and shoots cells [30]. In response to osmotic stress, plant cells can recover their turgor by increasing the mobility of inorganic ions [31]. However, when $\mathrm{Na}^{+}$ions reach a toxic level, they create a metabolic imbalance, triggering oxidative stress [32] and ROS overproduction [14,33]. This oxidative stress can disturb membrane stability, cause lipid peroxidation, damage nucleic acids, ion leakage, disruption, and posterior cellular death [34]. This section describes the effects of salt stress on germination, growth, yield and quality of cereals. 


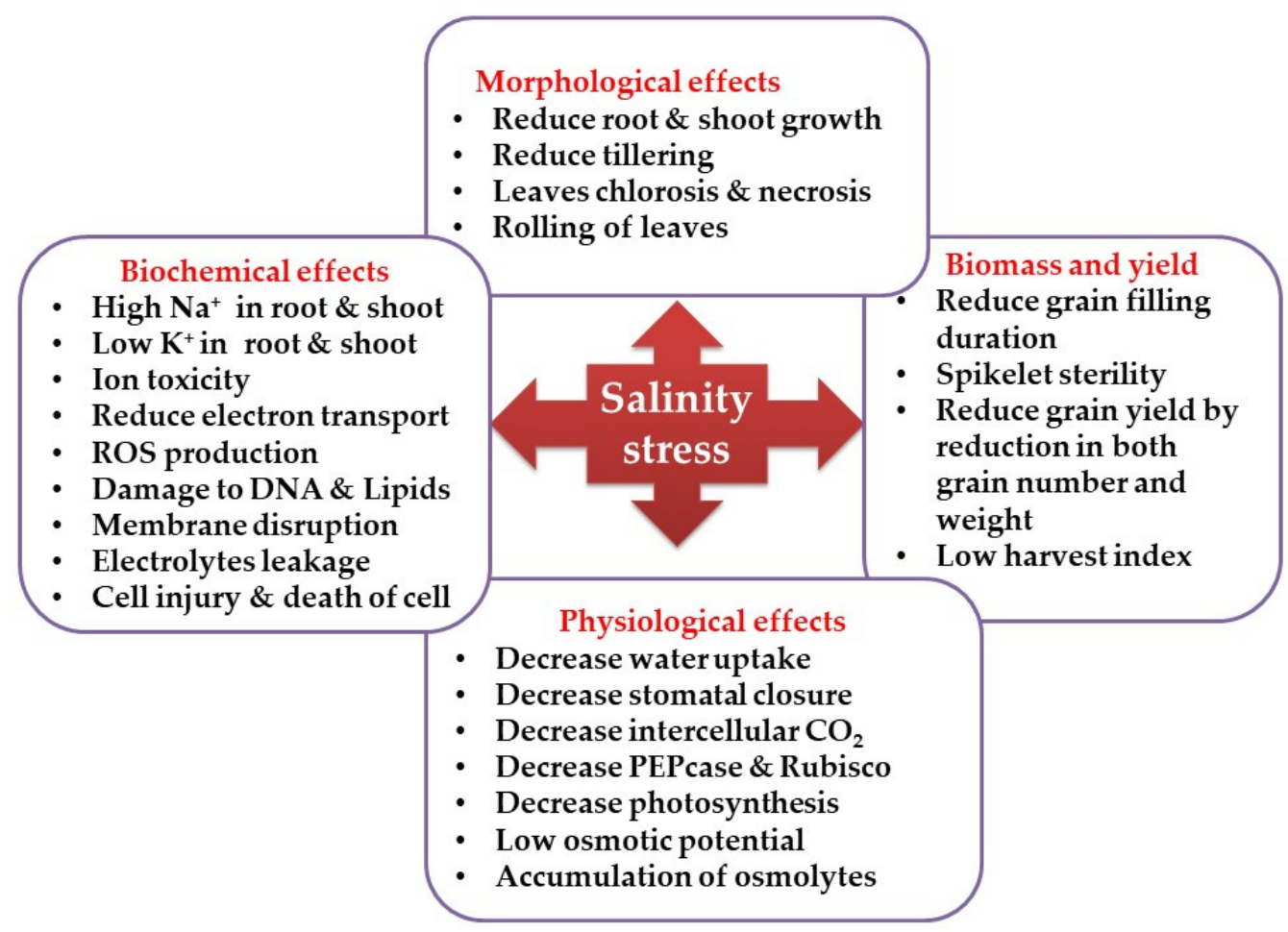

Figure 2. Morpho-physiological effect of salinity stress on cereal crops. PEPcase $=$ Phosphoenolpyruvate carboxylase.

\subsection{Seed Germination and Plant Growth under Salt Conditions}

The primary germination stage is the most critical process in the seedling establishment [6]. Soil salinity usually delays or even prevents seed germination [29]. Seed imbibition is affected by a high concentration of salts in the soil, reducing the water uptake by decreasing soil osmotic potential $[35,36]$. Moreover, the excess of $\mathrm{NaCl}$ can cause $\mathrm{Na}^{+}$ and $\mathrm{Cl}^{-}$toxicity to the seed embryos and alter protein synthesis, energy production, and respiration [35]. Thus, salinity stress can alter the seed's hormonal and nutrient balance during germination, resulting in delays in the germination time [37]. Changes in the hormonal status result from the changes in the activity of enzymes exposed to toxic ions. In salt-sensitive wheat cultivars, a decreased activity of $\alpha$-amylase during seed germination has been documented compared to salt-tolerant cultivars. Reducing the $\alpha$-amylase activity can reduce the sugars translocation into the developing embryo [38]. For example, when wheat and barley seeds were exposed to salt stress, between 40 and $120 \mathrm{nM}$, germination was reduced by $20 \%$ to $40 \%$, while seeds were not germinated with salinity levels of 160-200 nM (Table 1) [27].

Similarly, seed germination was reduced in wheat seeds exposed to salt stress $(150 \mathrm{mM})$ by $12.7 \%$ as average for 20 wheat genotypes compared to the control treatment [39]. In another study, germination of three genotypes of peanut (Arachis hypogaea L.) seeds sown with $200 \mathrm{mM}$ were reduced by $43.29 \%, 42.70 \%, 39.56 \%$ and $6.77 \%$ compared to those sown at $0,50,100$ and $150 \mathrm{mM}$, respectively [40]. The reduction in the percentage of germination observed in other studies with maize, rice, wheat, sorghum and barley is presented in Table 1.

Salinity stress significantly negatively impacts plant growth and development (Table 1); however, plants' responses can differ according to the extent of the plant's stress and the plant's growth stage. Overall, salinity affects plant growth in two phases [41]. The first phase of a decrease in plant growth occurs within minutes, where a high concentration of salts reduces the water uptake and growth rate due to the osmotic effects. The osmotic stress triggers numerous aspects in plant tissues. At the macroscopic level, expansion of both root and shoot cells is immediately obstructed due to a decreased turgor pressure $[42,43]$. To cope with this issue, the plant must adjust osmotically. Most of the turgor 
of the cell in the root is regained within 40-60 min by increasing the uptake of inorganic ions, and the growth is resumed $[30,44]$. Osmotic stress also causes quick stomatal closure, and the plant reduces $\mathrm{CO}_{2}$ assimilation, which results in a rapid decrease in the xylem pressure up to $0.05 \mathrm{MPa}$ in maize roots exposed to $100 \mathrm{mM} \mathrm{NaCl}$ [45]. Such a decrease in the xylem pressure occurs within minutes upon stress onset, and the hydraulic signals are sensed quickly by the roots. They are transduced almost instantaneously to the shoot, decoded and altering shoot metabolism [46,47]. Because stomatal guard cells possess a range of mechano-sensitive ion channels, they could potentially transduce a change in the xylem pressure caused by salinity into altered stomatal apertures [48,49]. Furthermore, plants grown under salt stress suffer physiological and metabolic changes such as reduced enzyme activity, $\mathrm{CO}_{2}$ assimilation, protein biosynthesis, leaves water relations, and photosystem II (PS II) [41,50].

In the second phase of growth reduction, salts accumulate in plant leaves, reaching threshold levels and causing toxicity. This phase is longer and can take a few days up to weeks or even months to complete [41]. During the second phase of growth reduction, higher $\mathrm{Na}^{+}$accumulation in the intracellular spaces can inhibit the enzymatic activities. For instance, the cytosolic compartment possesses different enzymes, which have a vital role in the starch synthesis, glycolysis, polyamine, phenylpropanoid pathway and Calvin cycle. The activity of these enzymes is mainly controlled by the $\mathrm{K}^{+}$concentration in the cytosolic space [51]. Due to the close similarity between $\mathrm{K}^{+}$and $\mathrm{Na}^{+}, \mathrm{Na}^{+}$replaces the $\mathrm{K}^{+}$in these enzymatic reactions but with much less efficiency [44,52]. Moreover, since $\mathrm{Na}^{+}$cations have a smaller "naked" radius than $\mathrm{K}^{+}$, they accumulate in regions of greater density, while $\mathrm{K}^{+}$ions tend to accumulate in less dense regions. This difference in the intracellular ions can impact cell operations, water relations and biosynthesis of proteins [53]. Bio-macromolecules with charged 3D structures occupy about 20-30\% of the cytoplasmic volume [53]. Studies showed that the functions of the bio-macromolecules are significantly influenced by the ionic strength and the electrostatic interactions of the cytoplasmic solution [54]. As a result, plants under the second phase of growth reduction show chlorosis, necrosis, premature leaf senescence and reduced leaf area due to the reduction in the photosynthetic activity and the overall cell metabolism [41]. The threshold level of ion toxicity varies for plant species and even among cultivars and hybrids. For example, the magnitude of grain yield reduction was lower (41\%) in an adapted wheat cultivar, while the maximum reduction $(68 \%)$ was observed for a susceptible cultivar at $120 \mathrm{mM}$. Based on their salt tolerance, plants are divided into halophytes and glycophytes. Halophytes are salt-tolerant plants, while glycophytes are very sensitive to salinity stress. Generally, cereals are typically glycophytes among cereals crops, sorghum and barley (70-90 mM NaCl) [55] are more tolerant than wheat, which is more tolerant than rice and maize. When salinity concentrations reach $100 \mathrm{mM} \mathrm{NaCl}$, rice usually does not reach maturity at the field conditions [56].

In contrast, wheat and barley can reach maturity, although the decreases in the grain yields are commonly more significant for wheat than barley. However, with salinity concentrations higher than $250 \mathrm{mM} \mathrm{NaCl}$, barley plants can die after extended periods of exposure [56]. In maize and rice, grain yields start to decline at much lower salt concentrations, $17 \mathrm{mM} \mathrm{NaCl}$ and $30 \mathrm{mM} \mathrm{NaCl}$, respectively, while yield decline in wheat occurs at higher concentrations (60-80 $\mathrm{mM} \mathrm{NaCl)} \mathrm{[57].}$ 
Table 1. Morphological effects on cereal crops under salt stress.

\begin{tabular}{|c|c|c|c|}
\hline Salinity Stress Level & Crop & Effects & Reference \\
\hline 40 to $120 \mathrm{mM}$ & \multirow{7}{*}{ Wheat } & $20-40 \%$ reduction in germination & [27] \\
\hline 160 to $200 \mathrm{mM}$ & & No germination & [27] \\
\hline $100-300 \mathrm{mM}$ & & $27-30 \%$ reduction in germination & [58] \\
\hline $100-250 \mathrm{mM}$ & & $15-31 \%$ reduction in germination & [59] \\
\hline $30-120 \mathrm{mM}$ & & $\begin{array}{l}20-38 \% \text { reduction in germination; } \\
41-67 \% \text { reduction in yield }\end{array}$ & {$[60]$} \\
\hline $100-150 \mathrm{mM}$ & & $\begin{array}{l}\text { decreased the dry weights and } \\
\text { chlorophyll contents }\end{array}$ & {$[61]$} \\
\hline $100-300 \mathrm{mM}$ & & $77-86 \%$ reduction in dry weight & [58] \\
\hline 100-200 mM & \multirow{4}{*}{ Sorghum } & $37-58 \%$ reduction in germination & [62] \\
\hline 100-200 mM & & $\begin{array}{l}26-28 \% \text { reduction in shoot and root } \\
\text { growth, respectively }\end{array}$ & {$[62]$} \\
\hline $30-60 \mathrm{mM}$ & & Reduced growth and dry matter & [63] \\
\hline $43.8 \mathrm{mM}$ & & $50 \%$ grain yield reduction & [64] \\
\hline $25-100 \mathrm{mM}$ & \multirow{6}{*}{ Maize } & $\begin{array}{l}15-20 \% \text { reduction in germination while } \\
\qquad>10 \% \text { yield reduction }\end{array}$ & [65] \\
\hline 60-130 mM & & Reduced germination & [66] \\
\hline $100 \mathrm{mM}$ & & Shoot and root growth reduced & {$[67]$} \\
\hline 100-200 mM & & $\begin{array}{l}\text { Germination, fresh and dry weight } \\
\text { reduced }\end{array}$ & {$[68]$} \\
\hline 75-150 mM & & $\begin{array}{c}\text { Reduction in root dry weight and } \\
\text { leaves }\end{array}$ & [69] \\
\hline $100-200 \mathrm{mM}$ & & Severe reduction in growth & [70] \\
\hline $80 \mathrm{mM}$ & \multirow{4}{*}{ Rice } & Plant height, tiller and yield reduced & [71] \\
\hline $60 \mathrm{mM}$ & & $50 \%$ reduction in yield & {$[72]$} \\
\hline $1.16-2.89 \mathrm{~g} \mathrm{NaCl} / \mathrm{kg}$ of soil & & $36 \%$ reduction in grain yield & [73] \\
\hline $18-66 \mathrm{mM}$ & & Reduction in shoot and dry root weight & [71] \\
\hline & \multirow{3}{*}{ Barley } & $\begin{array}{l}\text { Grain yield reduced from } \\
7812 \text { to } 997 \mathrm{~kg} / \mathrm{ha}^{-1}\end{array}$ & [74] \\
\hline 100-200 mM & & $\begin{array}{l}\text { shoot dry weight, shoot and root length } \\
\text { reduced }\end{array}$ & {$[75]$} \\
\hline 100-150 mM & & $15-25 \%$ reduction in germination & [76] \\
\hline
\end{tabular}

\subsection{Effect of Salinity on Grain Yield and Quality}

Studies showed that soil salinity could reduce tillers numbers, grains number, and harvest indexes in cereal crops [77]. For instance, salinity $\left(4 \mathrm{dS} \mathrm{m}^{-2}\right)$ reduced the number of grains and 1000-grain weight in rice cultivars [78]. However, the salt sensitivity of plants varies during their lifecycle, with the seedling and reproductive stages being the most salt-sensitive stages in cereals. At the crop's reproductive stage, soil salinity reduces grain filling duration and grain yield. Wheat plants produced lower grain yield when exposed to salinity stress at the reproductive stage [79], since plants have fewer compensatory mechanisms to cope with salts in sensitive reproductive tissues, resulting in enhanced floret sterility, a higher percentage of unfilled or partially filled grain, and reduced grain weight and yield [78]. Moreover, salinity stress down-regulates the expression of different genes involved in forming branch and spikelet meristems and reduces the number of grains. Zheng et al. [77] reported that salinity down-regulated Lax panicle 1,2 (LAX1, LAX2), Ideal plant architecture (IPA1), and Dense and erect panicle 1 (DEP1) genes in rice reduced the number of grains per panicle.

In cereals, carbohydrates are the central reserve of grains (50-70\%) followed by proteins (5-12\%) [78], which determine grain textural, nutritional and taste attributes. Studies showed that high salt concentrations could reduce amylose and starch contents and modulate grain texture $[66,67,74,80]$. These functional changes might be due to the starch-tostorage protein ratio of grains, distribution of the amylopectin chain, amylose content, the 
crystallinity of starch granules and particle size [78]. In maize, for example, grain protein content increased while carbohydrate decreased with increasing salt contents in irrigation water [80]. Salinity $\left(0.62-1.16 \mathrm{mS} \mathrm{cm}^{-1}\right)$ decreased grain yield by $36 \%$ in rice but did not influence grain texture compared to the control treatment [73]. In barley, salinity reduced grain size and carbohydrate content but increased protein. Contrary to barley [74], the salinity stress decreased the protein content in wheat grains [81].

\section{Mechanisms for Salt Stress Responses, Avoidance and Tolerance}

Most crops are glycophytes (salt-sensitive) and, thus, are significantly influenced by salt stress. Soil salinity induces three types of stress: osmotic stress, ionic stress, and secondary stress $[82,83]$. Osmotic stress reduces the plant ability to water uptake from the soil solution, which results in a water deficit in the plant. However, ionic stress is associated with a high concentration of $\mathrm{Na}^{+}$and $\mathrm{Cl}^{-}$ions in the metabolically active cell components and affects enzymatic activities [30]. The osmotic and ionic stresses cause secondary stresses such as nutrient imbalance, accumulation of toxic compounds, and ROS production. In response to these stresses, plants develop the tolerance mechanism to survive their growth (Figure 3). Here, we discuss the mechanisms of plants for salt stress responses, avoidance and tolerance.

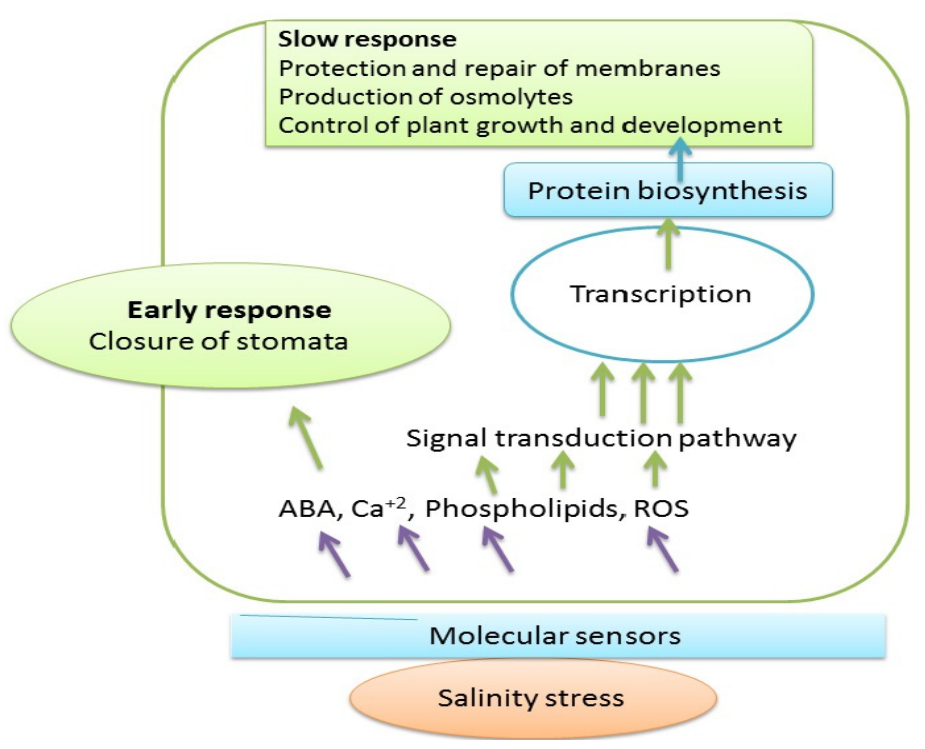

Figure 3. A simple representation of plant signal transduction pathways in response to salinity stress. Different phytohormones and molecular sensors are activated in response to salinity stress. For instance, phytohormones, i.e., ABA, are signal molecules in plants, transducing the quick response to salt stress and closing plant stomata. Biosynthesis of molecules through transcription, on the other hand, is a slow, much slower process.

\subsection{Sensing Salt Stress}

To avoid or reduce the damages caused by an excessive concentration of salts in the soil, plants must sense the salts stress, adjust cellular traits, and send signals to the interior of the cell (Figure 4). Studies showed that $\mathrm{Na}^{+}$could enter the cytoplasm through different cation exchange channels (Figure 4), such as NSCC (i.e., nonselective cation channel), the high-affinity $\mathrm{K}^{+}$channel (HKT1) and the low-affinity $\mathrm{K}^{+}$channel [82]. Excessive salinity increases the $\mathrm{Ca}^{2+}$ concentration in the cytosol of cells within seconds to minutes, induces $\mathrm{Ca}^{2+}$ signal, and initiates the $\mathrm{Na}^{+}$efflux pathway [84]. The $\mathrm{Ca}^{2+}$ binding proteins such as salt overly sensitive $\{\mathrm{SOS} 3$ and SOS3-Like calcium-binding protein 8 (SCaBP8)\} perceives the calcium signal. Then, the SOS3 and SOS2 proteins activate the SOS1, a Na $\mathrm{Na}^{+} / \mathrm{H}^{+}$exchanger, to exclude the cytosolic $\mathrm{Na}^{+}$into the apoplast [82]. Osmotic stress triggers the signals that enhance the biosynthesis and concentration of compatible osmolytes such 
as polyols, glycine betaine, and sugars. The increased concentrations of these compatible osmolytes in cytosol decrease the water losses and increase cell turgor pressure and expansion under salt stress conditions $[82,83]$.

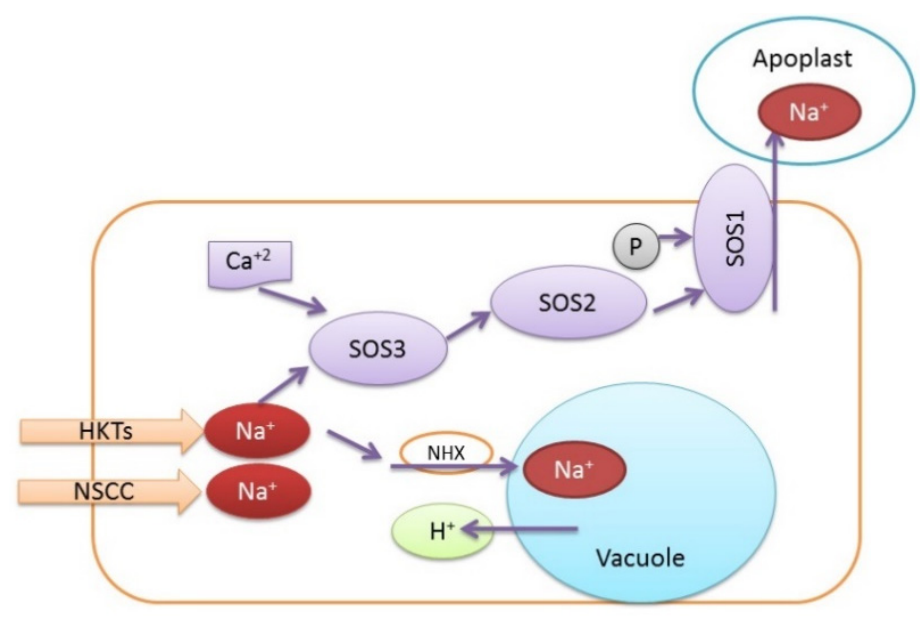

Figure 4. Simple illustration of $\mathrm{Na}^{+}$transport across cellular compartments.

\subsection{Tolerance Mechanisms}

To identify the strategies of stress-resistant crops for enhancing their resistance to individual and combined abiotic stresses (Figure 5), we reviewed a handful of sustainable strategies of crop management under abiotic stress. Salt tolerance mechanisms are complex processes that involve adaptations such as osmoregulation, hormonal regulation, osmotic adjustment, ion homeostasis, and activation of the antioxidant defense system.

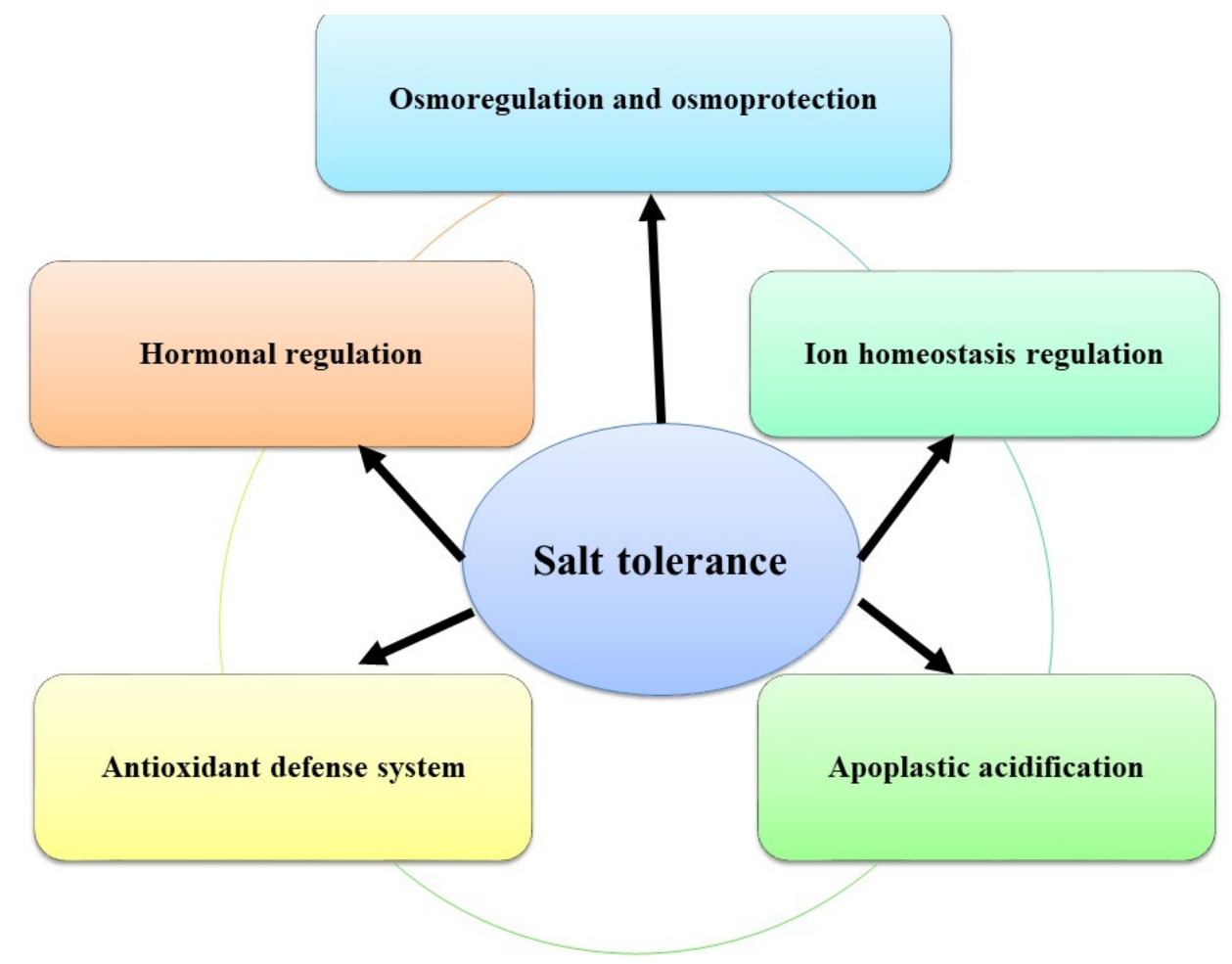

Figure 5. Mechanisms of salt tolerance in plant.

\subsubsection{Osmoregulation and Osmoprotectant}

Salinity can cause osmotic stress during the first phase of the salinity-induced growth reduction process. At this stage, plants adopt a strategy to minimize the adverse impact 
of osmotic stress through a mechanism known as osmoregulation [8]. To ameliorate the decrease in both cell water potential and stabilize their protein structures under stressful conditions, plants osmoregulate their water potential by either increasing the biosynthesis of organic solutes (polyols, sugars, amino acids, and other low molecular weight metabolites) or the inorganic solutes uptake $\left(\mathrm{K}^{+}, \mathrm{Ca}^{2+}\right.$, and $\left.\mathrm{Cl}^{-}\right)[30,82]$. The organic solutes and inorganic ions are involved in the osmotic adjustment, reducing the loss of water and increasing cell turgor and expansion. To do this, plants synthesize various types of compatible solutes such as glycine betaine, $\beta$-alanine betaine, proline, trehalose, and polyols under salt stress (Figure 6). In addition to regulating plant water relations and osmotic adjustment, these osmolytes help the enzymes to activate the plant's antioxidant defense system. Therefore, compatible solutes are called osmoprotectants $[8,79]$.

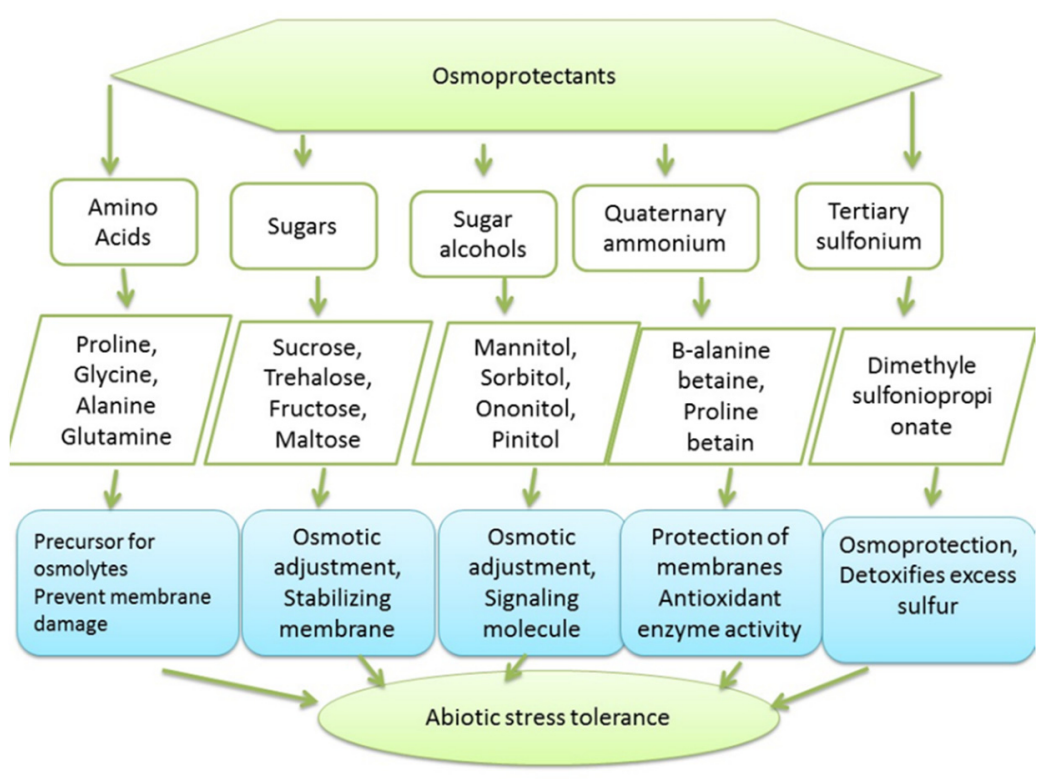

Figure 6. The role of osmoprotectants in abiotic stress tolerance. Under abiotic stress, plants accumulate different types of osmoprotectants. These have different roles, including stabilization and maintenance of cell membrane composition and structure, molecular signaling, and cell detoxification.

Salt-tolerant species achieves the osmotic adjustment via $\mathrm{Na}^{+}$distribution between cytoplasm and vacuole [85]. Thus, plants maintain their cytoplasmic osmotic pool to stabilize cellular metabolism and growth under salinity. For instance, salt-tolerant wheat cultivars exhibited higher glycine betaine, proline, soluble sugars and phenols, and maintained higher $\mathrm{K}^{+}$content by reducing the uptake of $\mathrm{Na}^{+}$under salinity stress. Likewise, barley and maize crops accumulated higher glycine betaine concentrations under salt stress than the control treatment [86].

\subsubsection{Ion Homeostasis Regulation}

Ion homeostasis is an essential mechanism for plants to be adapted during salt stress to mitigate the salinity's toxic effects. Keeping a high $\mathrm{K}^{+} / \mathrm{Na}^{+}$ratio in the cytosol can prevent cellular damage and increase the plant's ability to tolerate the salinity $[82,87]$. The plant can eliminate the absorbed $\mathrm{Na}^{+}$from the cells or compartmentalize it in less active cells such as vacuoles to maintain ion homeostasis. With this, plants can maintain ion homeostasis and equilibrium. Sodium-ion $\left(\mathrm{Na}^{+}\right)$enters the plant roots and reach the cytoplasm, and then through the support of various $\mathrm{Na}^{+} / \mathrm{H}^{+}$antiporters, it gets moved to the vacuole [88]. The primary type of $\mathrm{H}^{+}$-pumps present on the tonoplast is $\mathrm{H}^{+}$-ATPase, followed by V-phase [89]. $\mathrm{Na}^{+} / \mathrm{H}^{+}$antiporters (NHXs) such as NHX1 and NHX2 control $\mathrm{Na}^{+}$accumulation in vacuoles through tonoplast $\mathrm{Na}^{+} / \mathrm{H}^{+}$exchanger [90]. Another signaling pathway that plays an essential role in reducing $\mathrm{Na}^{+}$toxicity is the salt overly sensitive (SOS). $\mathrm{Na}^{+} / \mathrm{H}^{+}$antiporter (encoded by SOS1) regulates the $\mathrm{Na}^{+}$efflux 
from the cytosol and increases toxic ions' transportation from roots to shoots. SOS2 and SOS3 participate in $\mathrm{Ca}^{2+}$ mechanisms, which deal with $\mathrm{Na}^{+}$efflux.

Selective transporters of $\mathrm{Na}^{+}$maintain the equilibrium of $\mathrm{K}^{+}$and $\mathrm{Na}^{+}$in plant cells by excluding $\mathrm{Na}^{+}$ions from the cytosol to cell vacuoles [88]. Other studies indicated that maize, wheat and rice could exclude the $\mathrm{Na}^{+}$from leaves through the HKT1 channel [91-93]. Although plant cells can efficiently exclude excessive $\mathrm{Na}^{+}$from the cell or compartmentalize it in the vacuoles to avoid toxic effects in the cytoplasm [94], there is a wide variation between different cereals and among different genotypes for the same species for ion distribution within the cytosol. For instance, salt-tolerant cultivars of maize, wheat and rice exhibited distinctive transporters (HKT1) to retain a lower concentration of $\mathrm{Na}^{+}$in the cytosol $[91,93]$. In barley, H. maritimum plants maintained a lower concentration of $\mathrm{Na}^{+}$and $\mathrm{Cl}$ and a higher concentration of $\mathrm{K}^{+}$in leaves than $H$. vulgare [95].

\subsubsection{Apoplastic Acidification}

Salinity stress indirectly affects the cell wall property by causing an alteration in the gene expression; however, $\mathrm{Na}^{+}$physically interacts with different cell wall components directly and changes their chemical properties [96]. Excessive soil salinity can lead to a high concentration of $\mathrm{Na}^{+}$in the apoplast, increasing the interaction between $\mathrm{Na}^{+}$and negatively charged sites in the cell wall and influencing the apoplast's $\mathrm{pH}$. According to the acid growth theory, salinity can cause apoplast's temporary alkalization, limiting the cell wall growth [97]. Under the usual conditions, auxin triggers the plasma membrane $\mathrm{H}^{+}$-ATPases, and protons are exuded into the apoplast, decreasing its $\mathrm{pH}$. The acidification of the apoplast activates the expansins and several other enzymes, resulting in the loosening of the cell wall [96]. Poor cell wall acidification can reduce cell wall expansion, and with this, overall plant growth. For example, maize seedlings showed impaired growth under salinity stress because of plasma membrane $\mathrm{H}^{+}$-pumping's inefficiency. In contrast, salt-tolerant maize cultivars exhibited a growth rate due to efficient $\mathrm{H}^{+}$-pumping, which reduced the $\mathrm{pH}$ of apoplast under salt stress [98]. In short, acidification of apoplast under salinity stress is required for cell wall loosening, an indicator of salt resistance.

\subsubsection{Antioxidant Defense System}

Soil salinity can cause nutrient imbalance, disrupt the plant metabolic functions and increase the production of ROS. These ROS influence cellular functions and damage the structure of membrane lipids, DNA, resulting in leakage of cell solutes. ROS is produced at different cell sites such as chloroplast, plasma membrane, apoplast, mitochondria, endoplasmic reticulum, and cell wall [8]. Plants increase the production of ROS-scavenging enzymes and non-enzymes [99]. Antioxidant enzymes work as scavengers to detoxify ROS in plants and improve the resistance of plants under stress (Figure 7). For example, superoxide dismutase (SOD) is a scavenger of superoxide $\left(\mathrm{O}_{2}{ }^{-}\right)$. It converts it to $\mathrm{H}_{2} \mathrm{O}_{2}$, while catalase (CAT) scavengers of $\mathrm{H}_{2} \mathrm{O}_{2}$ are converted into $\mathrm{H}_{2} \mathrm{O}$ and $\mathrm{O}_{2}{ }^{-}$[100]. Increasing antioxidant enzymes'activities and developing antioxidant metabolism is vital to enhance salts tolerance. For example, wheat plants enhanced SOD, GR, APX and glutathione peroxidase (GPX) under $\mathrm{NaCl}$ stress $(100 \mathrm{mM})$ for 30 days [99]. Barley plants had high CAT activities, SOD, APX while lower MDA content under salinity stress after application of Se-nanoparticles [75,101]. However, Habibi and Aleyasin [75] reported that excessive salts stress reduced the activity of SOD but increased the activity of malondialdehyde (MDA) in barley plants. Sorghum plants could increase antioxidant enzymes'activities to adapt to salinity stresses [100]. Studies showed that different non-enzymatic antioxidants such as glutathione, phenols, flavonoids and free proline catalyzed redox reactions [102]. Ascorbic acid (ASA) stimulates vegetative growth by increasing cell division and elongation under salinity stress because ASA can detoxify and neutralize the ROS [103]. Similarly, an exogenous spray of thiamin enhanced the antioxidative defense system in maize plants exposed to salt stress [104]. This enhancement in maize growth was attributed to the reaction between thiamin and adenosine triphosphate (ATP) to form thiamin diphosphate (ThDP), 
which could work as an active co-enzyme for carbohydrate metabolism and transmetallation (a reaction involving the transfer of a ketole group) reaction of pentose phosphate in the Calvin cycle [105]. Similarly, plant enhances the biosynthesis of phenolic compounds, which act as scavengers and donate a hydrogen atom to the ROS, thus stabilizing free radical reactions [106]. Flavonoids, secondary metabolites phenolic compounds with low molecular weight, also have antioxidant potential against ROS [107]. Thus, increased enzymatic and non-enzymatic antioxidants in plants is essential in plants exposed to salinity stress [91].

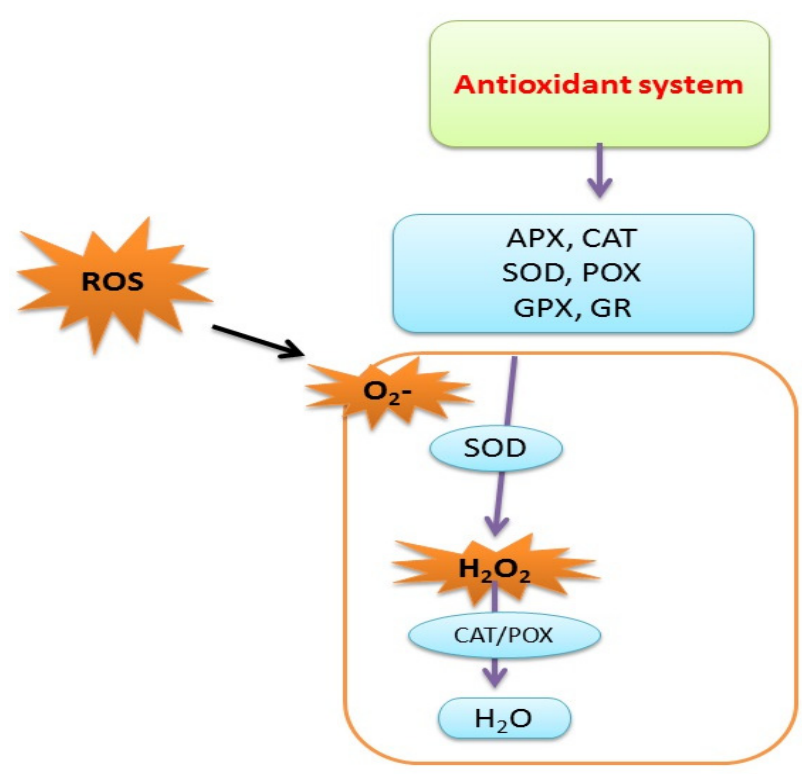

Figure 7. Simple illustration of detoxification of ROS through antioxidants. A plant cell has various antioxidant enzymes which detoxify the ROS. They work in a series. For instance, $\mathrm{O}_{2}{ }^{-}$is scavenged by SOD, which converts $\mathrm{O}_{2}$ - into $\mathrm{H}_{2} \mathrm{O}_{2}$, whereas CAT converts $\mathrm{H}_{2} \mathrm{O}_{2}$ into $\mathrm{H}_{2} \mathrm{O}$ and $\mathrm{O}_{2}$.

\subsubsection{Hormonal Regulation}

Phytohormones are biosynthesized in plants in minimal quantities, but they play fundamental roles in plants' growth and development. Among different phytohormones, abscisic acid (ABA), salicylic acid (SA), jasmonic acid (JA) and ethylene are known as stress response hormones. While auxin, cytokinins (CKs), gibberellin (GA), strigolactones (SLs) and brassinosteroids (BRs) are regarded as growth-promoting hormones [108]. These hormones generate and transmit a specific defense signal, while synergistic or antagonistic cross-talks among hormones emerge as pivotal for resistance outcomes. Plants have complex cellular and molecular mechanisms to adapt and ensure survival under unfavorable environmental conditions.

The adaptation of plant responses to abiotic stress is controlled by the hormonal signaling cascades that regulate stress responses under unfavourable growth conditions. In response to water stress, several phytohormones such as ABA, GA, JA, SA, and ET acted together and up-regulated 859 genes in A. thaliana [109]. Similarly, JA and ABA show synergistic effects in signaling pathways to regulate each other responses against salinity, drought and cold stress [110]. Alike, ethylene (ET) and JAs play an essential role in plants subjected to drought, cold stress, and salinity stress in a synergistic and antagonistic manner [111,112]. Studies showed that the external application of JA and SA could improve drought stress tolerance in wheat. Similarly, the ABA and JA showed an antagonistic effect in plant growth during signaling pathways while operating synergistically in response to environmental stress [110].

Furthermore, each plant hormone does not perform a single role in plants, but it plays different roles in different tissues at various plant stages under different environmental stresses $[113,114]$. For example, endogenous ABA concentration increases rapidly, activat- 
ing sucrose nonfermenting 1-related protein kinases (SnRK2s). SnRK2s further regulate the stomatal closure in plants osmotic stress [115]. Plant root tip first senses the reduced water availability due to osmotic stress and sends the signal to plants' aerial parts (shoots) through ABA. The salt-tolerant plant has higher ABA accumulation under salt stress than salt-sensitive [116]. Recent studies showed shoot ABA synthesis, while root ABA biosynthesis is minimal and scarcely influences the shoot physiology. McAdam et al. [117] reported that exceedingly rapid de novo biosynthesis of ABA as exogenous application, throughout the up-regulation of a single gene in the pathway of ABA-biosynthetic, initiatives ABA-mediated stomatal reactions to vapor pressure deficit in angiosperms.

In contrast, GA is a phytohormone that induces salt tolerance in plants. For example, rice plants regulated the GA to tolerate salt stress [23]. Wheat plants with an elevated JA level exhibited salt tolerance [118], while low biosynthesis of JA in rice caused hypersensitivity to salinity [119]. These studies indicate that elevated phytohormones levels in plants under salt stress help reduce water loss and even promote the growth of cereal crops.

\section{Management Strategies to Alleviate the Adverse Effects of Salt Stress}

The production of salt-tolerant genotypes is essential to sustain crop production in saltprone areas. Recent developments in physiology, biotechnology, genomics, and breeding approaches can produce cereals cultivars suitable for salt-affected areas. Here we describe the feasible and cost-effective strategies to overcome salt stress in cereal.

\subsection{Alleviation of Salt Stress by Nanoparticle Elements}

Nanoparticles (NPs; 1-100 nm in size) have enormous potential to help different scientific fields such as biological science, medical, industrial, and agricultural sciences [120,121]. Nanoparticles are applied as nano fertilizers and nano pesticides in agriculture to increase crop yield and productivity under normal and stressful conditions [9,122]. The application of nanoparticles or nano fertilizers could be a helpful technique to overcome soil salinity (Table 2). Nanoparticles have been reported to enter plant cells to adjust osmotic imbalance for enhancing water uptake [123]. During seed germination, the nanomaterials penetrate the seed tissues through intercellular spaces or create new pores primarily through the up-regulation of aquaporin production [124,125] and up-regulate the genes involved in various processes, including cell divisions [126]. The application of $\mathrm{ZnO}$ and $\mathrm{TiO}_{2}$ nanoparticles successfully revived embryonic differentiation by helping the enzymes break the seed dormancy [124]. Multi-walled carbon nanotubes used in tomato seed treatment caused an up-regulation of genes such as $C y c B, N t L R X 1$, extensin and NtPIP1 involved in cell divisions, cell wall formation and water transport, respectively. They increased the final germination of tomatoes [126]. In other cases, nanoparticles have been shown to enhance the transcription of genes that confer the cell with an increased antioxidant capacity. Under abiotic stress, nanocarbon tubes increased the germination of seeds and growth of seedlings by decreasing lipid peroxidation and $\mathrm{H}_{2} \mathrm{O}_{2}$ production by enhancing sodium oxide dismutase (SOD), catalase (CAT), peroxidase (POD) activities and ascorbic acid (ASA) [127]. However, higher concentrations of NPS can promote ROS production and increase cellular damage, disrupt protein function and DNA, and interfere with signaling function and gene transcription modulation [128].

Salt stress damages cell membranes and other cellular compounds such as lipids and proteins. A recent study showed that ZnO-NPs triggered the anti-stress enzymes, which significantly reduced malondialdehyde (MDA) levels (72\%) and lipid peroxidation in coriander (Coriandrum sativum L.) leaves [129]. Alike, acidic ribosomal phosphoproteins contain phosphorylated residues and perform a vital role in protein synthesis and regulation. Moreover, while $\mathrm{NaCl}$ stress reduces acidic ribosomal phosphoprotein (ARP) gene expression, there is evidence that the application of $\mathrm{ZnO}-\mathrm{NPs}$ can enhance the ARP gene expression under salinity stress [130]. Myelocytomatosis oncogenes (MYCs) proteins are also negatively impacted under saline stress. These proteins are involved in different processes, including stomatal differentiation, biosynthesis of anthocyanins, root hair forma- 
tion, embryonic epidermis seed germination, endosperm breakdown, signaling pathways of abscisic acid (ABA), jasmonate, and increased tolerance to biotic and abiotic stresses. ZnO-NPs triggered the MYCs proteins under salinity stress in rapeseed (Brassica napus L.), although the mechanism behind this response is not yet clear [130]. Several other studies showed different beneficial effects of NPs. For example, applying silver nanoparticles (Ag-NPs) to rice under salinity stress conditions increased the germination rates and reduced the toxic effects of salts. The increase in seed germination under salt stress after applying nanoparticles might be due to better penetrability of nanoparticles into the seed pores, which increased the water uptake and maintained enzymatic activities of seeds [99]. Combine application of $\mathrm{ZnO}-\mathrm{NPs}(0.8 \mathrm{~g} / \mathrm{L})$, and biofertilizers increased the grain yield of Triticale (X Triticosecale Wittm. ex A. Camus.) by 39\% under high salt-stressed soils (55.5 mM) [131]. Similarly, ZnO-NPs (25-50 $\left.\mathrm{mg} \mathrm{L}^{-1}\right)$ increased rice plants' fresh and dry weight exposed to salinity stress, improved water relations, and final paddy yield. Application of nano-Fe $(2 \mathrm{~g} / \mathrm{L})$ increased the plant growth and grain yield of wheat exposed to salt stress and increased the grain protein and iron contents [132].

Salt stress significantly decreases plant photosynthetic efficiency due to $\mathrm{Na}^{+}$and $\mathrm{Cl}^{-}$ ions $[133,134]$. High $\mathrm{Na}^{+}$concentrations in the cytosol decreased the activity of photosynthetic machinery, particularly photosystem-II (PSII), by disturbing the oxygen-evolving complex (OEC), PSII reaction centers and also by reducing the activity of quinine acceptors and the quantum yield of PSII [135]. As a result, the quantity of absorbed light exceeds the demand for photosynthesis, leading to ROS formation in green tissues [136]. High salinity also decreases the utilization of nicotinamide adenine dinucleotide phosphate (NADPH) via the C3-cycle, decreases rubisco (ribulose 1,5-bisphosphate carboxylase/oxygenase) activity and consequently decreases $\mathrm{CO}_{2}$ carboxylation [137]. Wang et al. [138] reported that high salinity levels decreased mesophyll conductance by decreasing carboxylation, reducing total chlorophyll content, degraded chloroplast structure, and disrupting the electron transport chain [139]. In the case of chloroplasts, a vital photosynthetic organelle in plants that contributes to the biosynthesis of vitamins, amino acids, fatty acids, lipids and isoprenoids, salt stress affects vital associated organelles such as the thylakoid membrane, increases oxidative stress, and impairs the osmotic and ionic homeostasis [140]. Several studies showed that nanoparticles application could reduce the adverse toxic effects of $\mathrm{Na}^{+}$ and $\mathrm{Cl}^{-1}$ on photosynthesis. For example, Ag-NPs application in wheat increased photosynthesis due to stimulatory effects by an unknown mechanism and biomass accumulation under saline conditions by reducing $\mathrm{Na}^{+}$translocation from roots to shoots and decreasing $\mathrm{H}_{2} \mathrm{O}_{2}$ and MDA content [61]. Application of ZnO-NPs increases the production of carbonic anhydrase, a zinc metalloenzyme that facilitates $\mathrm{CO}_{2}$ utilization in plants and, consequently, increases photosynthesis. Applying $\mathrm{SiO}_{2}-\mathrm{NPs}$ increased leaf dry weight and the proline, chlorophyll, and antioxidant contents in salt-stressed sweet basil (Ocimum basilicum L.) plants [141]. Silver nanoparticles decreased ROS production and lipid peroxidation in wheat plants under salt-stressed conditions [99]. The reduced ROS and lipid peroxidation production under salinity stress might be due to scavenging system activation through ascorbate-glutathione cycle-mediated, which inhibited lipid peroxidation and modulated the $\mathrm{K}^{+}$efflux $[99,142]$. Application of nanoparticles increased $\mathrm{K}^{+}$ions in wheat leaves, resulting in enhanced plant growth by decreasing uptake of $\mathrm{Na}^{+}$and $\mathrm{Cl}^{-}$in roots and posterior translocation to shoots [143]. The possible mechanism is that $\mathrm{Zn}$ ions accumulate in the apoplast, and the released $\mathrm{Zn}$ ions are absorbed by mesophyll cells.

Further, ZnO-NPs triggered the anti-stress enzymes, which are helpful to reduce salt effects [144]. Similarly, the application of Ag-NPs increased the chlorophyll content in wheat by enhancing the PS-II quantum efficiency and photosynthesis-related enzymes activity $[143,145]$. Studies showed that Ag-NPs (300 ppm) increased the activity of superoxide dismutase (SOD), ascorbate peroxidase (APX), glutathione reductase (GR), and glutathione peroxidase (GPX) up to $44 \%, 82 \%, 89 \%$, and $20 \%$, respectively in wheat plants that grown under salt conditions [99]. 
Table 2. Effect of nanoparticles on growth and development under salt-stressed conditions.

\begin{tabular}{|c|c|c|c|}
\hline Crop & Nanoparticles/Elements & Effects & References \\
\hline Barley & $\begin{array}{c}\text { Nano- } \mathrm{TiO}_{2}(500-2000 \mathrm{mg} \\
\left.\mathrm{kg}^{-1}\right)\end{array}$ & $\begin{array}{c}\mathrm{n}-\mathrm{TiO}_{2} \text { increased the growth and } \\
\text { photosynthesis rate of barley. Increased } \\
\text { activities CAT, SOD, and APX while } \\
\text { decreasing malondialdehyde (MDA) } \\
\text { content }\end{array}$ & [101] \\
\hline Barley & nano chitosan $(0.1-0.3 \%)$ & $\begin{array}{l}\text { Increased plant height, fresh and dry } \\
\text { weight, and leaf area }\end{array}$ & [76] \\
\hline Barley & Se nanoparticles & $\begin{array}{l}\text { Increased total phenolic contents and } \\
\text { reduced MDA activity }\end{array}$ & [75] \\
\hline Wheat & Ag-NPs $(2-10 \mathrm{mM})$ & $\begin{array}{l}\text { Increased fresh and dry weights and } \\
\text { chlorophyll contents }\end{array}$ & [61] \\
\hline Wheat & Nano- $\mathrm{Fe}_{2} \mathrm{O}_{3}$ and $\mathrm{ZnO}$ & $\begin{array}{c}\text { Increased shoot dry weight, plant height } \\
\text { and leaf area }\end{array}$ & [146] \\
\hline Wheat & Ag NPs & Increased growth, chlorophyll contents & {$[61]$} \\
\hline Wheat & AgNPs & $\begin{array}{c}\text { Increased chlorophyll, ascorbate content } \\
\text { up to } 26 \%\end{array}$ & [99] \\
\hline Maize & $\mathrm{ZnO}-\mathrm{NPs}$ & Increased antioxidant enzymes & {$[61]$} \\
\hline Maize & nano chitosan & $\begin{array}{l}\text { Increased chlorophyll content, PS II } \\
\text { activity, and an overall improvement in } \\
\text { maize growth }\end{array}$ & [77] \\
\hline Maize & Nano- $\mathrm{ZnO}$ and $\mathrm{Fe}_{2} \mathrm{O}_{3}$ & $\begin{array}{l}\text { Increased root growth }(17 \%) \text {, net } \mathrm{CO}_{2} \\
\text { assimilation rate }(8 \%) \text {, leaf } \mathrm{Fe}(22 \%)\end{array}$ & [146] \\
\hline Maize & Metal NPs & $\begin{array}{l}\text { Reduced ROS production by increasing } \\
\text { antioxidants enzymes }\end{array}$ & [147] \\
\hline Rice & $\mathrm{ZnO}-\mathrm{NPs}$ & Improved SOD production & [148] \\
\hline
\end{tabular}

\subsection{Alleviation of Salt Stress by Agronomic Practices}

The efficient and sustainable management of farm resources can mitigate and overcome salinity adverse effects [15]. Soil salinity can be reclaimed through salt leaching from the rhizosphere, alteration in agronomic practices at the farm level, and introduction of salt-tolerant crops [149]. Some agronomic practices that can halt salinity and mitigate its adverse effects on crops are discussed below:

Chemical amendments: Certain soil chemical amendments, i.e., adding sulfuric acid, sulfur and gypsum, can be used to ameliorate the adverse effects of soil salinity stress [14]. Although, this needs special care in their application due to the corrosive nature of the acid. Likewise, through gypsum amendments, calcium replacement with sodium ions can decrease salinity adverse effects $[149,150]$. With gypsum application, the sodium ions move downward in the soil through drainage with irrigation water. The addition of $\mathrm{H}_{2} \mathrm{SO}_{4}$ and elemental sulfur can also reduce the soil $\mathrm{pH}$ due to the increment of $\mathrm{H}_{3} \mathrm{O}^{+}$in the soil solution [151].

Fertilization: Soil salinity can also be enhanced by fertilizer application to crops. To alleviate the adverse effects of the fertilizers, application method, timing, fertilizers characteristics, and composition should be kept in mind while applying fertilizers to the field [152]. Less frequent fertilizer application with high purity, low saline and chloridefree contents should be applied. Fertigation is also considered as a best practice that can decrease soil salinization and mitigate salinity stress. Sulfuric acid and nitric acid fertigation can reduce soil $\mathrm{pH}$ and increase $\mathrm{Ca}^{2+}$ ions in clay soil, decreasing the salinity stress injury and reducing the chloride salinity in the rhizosphere [153]. Soil with high $\mathrm{CaCO}_{3}$ may be reclaimed through $\mathrm{H}_{2} \mathrm{SO}_{4}$ fertigation. For optimum Fe availability, its application in chelated form is recommended. In addition, $\mathrm{NO}_{3}{ }^{-}, \mathrm{Ca}^{2+}, \mathrm{K}, \mathrm{P}$, silicon and salicylic acid application can enhance the salinity tolerance in different crops [154-157]. On the other hand, the humic acid application can also halt salinity stress by enhancing salt tolerances in crops. 
Salt tolerant crops: The most crucial strategy for salinity problems is salt-tolerant crops. Different crops can tolerate the salinity in general, i.e., sugar beet, cotton, and barley. Among cereals, paddy rice, sugarcane, rye, and pearl millet can grow on saline soils. Leaching maintenance: For salinity maintenance on arable fields, leaching maintenance is necessary. Irrigation water applied with known volume must accompany the volume of water drained out from the rhizosphere, which is extra water required for regular irrigation. For successful long-term irrigation, leaching is necessary, and the frequency of leaching is dependent on evaporation demand, soil salinization, and crops sensitivity to salinity [154]. This leaching washes the salts from the root zone and enables the plants to thrive [158].

Cover crops and mulching: The incidence of high evapotranspiration brings the soil surface more saline. Salinity in the soil is dependent on water table depth and irrigation water salinity concentrations [159]. Certain practices that flux the water table downward and reduce evapotranspiration through mulching reduce the soil salinity in the root zone [160].

Grafting: Grafting is considered an essential practice that reduces yield losses due to salinity in cucurbits. It prevents salinity stress by inhibiting the plants' $\mathrm{Na}$ and $\mathrm{Cl}$ uptake, which are the main sources of salinity in the soil $[154,161]$. Microbial remediation: the microorganisms colonize the root zones and enhance plant growth under different circumstances through direct and indirect mechanisms [162]. For salinity stress alleviation, the use of plant growth-promoting bacteria (PGPB) is beneficial and gaining the interest of the researchers. Plant growth-promoting rhizobacteria (PGPR) enhances plant growth by indirectly reducing the incidence of pathogens and diseases or enhancing nutrient uptake with the production of phytohormones. Literature also showed that arbuscular mycorrhiza fungi improve plant growth under salinity stress [163]. The inoculation of PGPR and other microbes is a potential strategy for salinity stress alleviation in salinity susceptible crops [164]. Different genera of salt-tolerant PGPR have been isolated for extreme saline, sodic and alkaline soils.

\section{Future Research}

Cereal crops are the primary source of food for millions of people around the world. Many efforts are required to increase cereal crops' production to meet the growing population's increasing food demand. Various abiotic stress such as drought, high temperature, heat stress, heavy metal, and salinity stress negatively affects cereal crops' growth and productivity. Among these stresses, the negative effect of medium and high soil salinity concentrations is likely the most critical and pervasive globally. Soil salinity reduces seed germination, growth, yield and quality. However, few studies are available regarding the effect of salinity on the grain quality of cereals.

Under salt stress, plants adopt different tolerance mechanisms to maintain their growth. However, the sensitivity of cereals significantly differs among species.

The use of salt-tolerant genotypes obtained through conventional and biotechnological approaches and the application of nanoparticles, osmolytes and hormones have been among the most efficient approaches to cope against the adverse effects of medium and high salinity concentrations in agricultural soils. Although some success has been recorded in releasing the salt-tolerant cereals lines or cultivars, most of the work has been done on wheat, rice, and maize, while few reports are available on barley and sorghum. Thus, there is a need to develop more salt-tolerant sorghum and barley cultivars for salt-stressed areas worldwide.

Finally, while most studies regarding salt stress have only focused on the negative effect of $\mathrm{NaCl}$ in soil, other types of salts are also present in the soil and water and may induce salinity in soils. Thus, future research should consider studying the behavior in the soil and the agronomic impact of other salts in crop growth and productivity.

\section{Conclusions and Recommendations}

Soil salinity is a significant threat to crop production and food security. The development of salt adapted crops is the most effective way to overcome this abiotic stress. Soil salinity affects plant physicochemical properties and causes osmotic and oxidative stress, 
severely decreasing cereals' growth, yield and quality. Salt tolerance by plants is governed by multi-physiological and molecular mechanisms such as ionic, tissue and osmotic stress. Therefore, significant progress has been made, and many studies have been conducted to understand salt stress mechanisms in plants. However, much more studies are needed to develop salt adapted crops. Besides, the development of salt adapted crops through conventional breeding is prolonged. Understanding both sensing and signaling metabolic pathways of plants under abiotic stress is essential to understand the role of other nutrients such as $\mathrm{K}^{+}$for salt induction and the salt tolerance genes in different crops to mitigate the salinity. Furthermore, with the advancements in biotechnology, genetic engineering, and genomics, we expect more salt adapted genotypes to become more extensively available for different edaphoclimatic conditions.

Author Contributions: Conceptualization, M.F.S. and O.A.H.; software, H.M.A., M.L.B., R.S.J. and B.A.A.; validation, C.S., N.A. and A.A.-D.; investigation, M.F.S., O.A.H., M.L.B., C.S.; data curation, A.A.-D., H.M.A., R.S.J., B.A.A.; writing-original draft preparation, M.F.S., O.A.H., H.M.A., R.S.J. and B.A.A.; writing-review and editing, M.L.B., C.S., N.A. and A.A.-D. All authors have read and agreed to the published version of the manuscript.

Funding: This research received no external funding.

Institutional Review Board Statement: Not applicable.

Informed Consent Statement: Not applicable.

Data Availability Statement: All data are presented within the article.

Conflicts of Interest: The authors declare that they have no conflict of interest.

\section{References}

1. Zenda, T.; Liu, S.; Duan, H. Adapting Cereal Grain Crops to Drought Stress: 2020 and Beyond. In Abiotic Stress in Plants; IntechOpen: London, UK, 2020.

2. Bhargava, A.; Srivastava, S. Participatory Plant Breeding Across Continents. In Participatory Plant Breeding: Concept and Applications; Springer Science and Business Media LLC: Berlin/Heidelberg, Germany, 2019; pp. 109-127.

3. Weidhuner, A.; Afshar, R.K.; Luo, Y.; Battaglia, M.; Sadeghpour, A. Particle Size Affects Nitrogen and Carbon Estimate of a Wheat Cover Crop. Agron. J. 2019, 111, 3398-3402. [CrossRef]

4. Adeyemi, O.; Keshavarz-Afshar, R.; Jahanzad, E.; Battaglia, M.L.; Luo, Y.; Sadeghpour, A. Effect of Wheat Cover Crop and Split Nitrogen Application on Corn Yield and Nitrogen Use Efficiency. Agronomy 2020, 10, 1081. [CrossRef]

5. Ramirez-Cabral, N.Y.Z.; Kumar, L.; Shabani, F. Global alterations in areas of suitability for maize production from climate change and using a mechanistic species distribution model (CLIMEX). Sci. Rep. 2017, 7, 5910. [CrossRef]

6. Dehnavi, A.R.; Zahedi, M.; Ludwiczak, A.; Perez, S.C.; Piernik, A. Effect of Salinity on Seed Germination and Seedling Development of Sorghum (Sorghum bicolor (L.) Moench) Genotypes. Agronomy 2020, 10, 859. [CrossRef]

7. Kromdijk, J.; Long, S.P. One crop breeding cycle from starvation? How engineering crop photosynthesis for rising $\mathrm{CO}_{2}$ and temperature could be one important route to alleviation. Proc. R. Soc. B Biol. Sci. 2016, 283, 20152578. [CrossRef] [PubMed]

8. FAO. The Future of Food and Agriculture-Trends and Challenges; Food and Agriculture Organization of the United Nations: Rome, Italy, 2017; p. 296.

9. Seleiman, M.F.; Almutairi, K.F.; Alotaibi, M.; Shami, A.; Alhammad, B.A.; Battaglia, M.L. Nano-Fertilization as an Emerging Fertilization Technique: Why Can Modern Agriculture Benefit from Its Use? Plants 2020, 10, 2. [CrossRef] [PubMed]

10. Battaglia, M.L.; Lee, C.; Thomason, W. Corn Yield Components and Yield Responses to Defoliation at Different Row Widths. Agron. J. 2018, 110, 210-225. [CrossRef]

11. Battaglia, M.; Lee, C.; Thomason, W.; Fike, J.; Sadeghpour, A. Hail Damage Impacts on Corn Productivity: A Review. Crop. Sci. 2019, 59, 1-14. [CrossRef]

12. Adnan, M.; Fahad, S.; Zamin, M.; Shah, S.; Mian, I.A.; Danish, S.; Zafar-Ul-Hye, M.; Battaglia, M.L.; Naz, R.M.M.; Saeed, B.; et al. Coupling Phosphate-Solubilizing Bacteria with Phosphorus Supplements Improve Maize Phosphorus Acquisition and Growth under Lime Induced Salinity Stress. Plants 2020, 9, 900. [CrossRef]

13. Thomason, W.; Battaglia, M. Early defoliation effects on corn plant stands and grain yield. Agron. J. 2020, 112, 5024-5032. [CrossRef]

14. Ding, Z.; Kheir, A.S.M.; Ali, O.A.M.; Hafez, E.M.; ElShamey, E.A.; Zhou, Z.; Wang, B.; Lin, X.; Ge, Y.; Fahmy, A.E.; et al. A vermicompost and deep tillage system to improve saline-sodic soil quality and wheat productivity. J. Environ. Manag. 2020, 277, 111388. [CrossRef] [PubMed] 
15. Sabagh, A.E.; Çĭ̆g, F.; Seydoşoğlu, S.; Battaglia, M.L.; Javed, T.; Iqbal, M.A.; Mubeen, M.; Ali, M.; Ali, M.; Bengisu, G.; et al. Salinity stress in maize: Effects of stress and recent developments of tolerance for improvement. In Cereal Grains; IntechOpen: London, UK, 2021.

16. Taha, R.S.; Seleiman, M.F.; Alhammad, B.A.; Alkahtani, J.; Alwahibi, M.S.; Mahdi, A.H. Activated Yeast extract enhances growth, anatomical structure, and productivity of Lupinus termis L. plants under actual salinity conditions. Agronomy 2021, 11, 74. [CrossRef]

17. Kim, N.; Jeon, J.; Elbert, J.; Kim, C.; Su, X. Redox-mediated electrochemical desalination for waste valorization in dairy production. Chem. Eng. J. 2021, 428, 131082. [CrossRef]

18. Mughal, M.; Sers, C.F. Cereal production, undernourishment, and food insecurity in South Asia. Rev. Dev. Econ. 2020, 24, 524-545. [CrossRef]

19. Seleiman, M.F.; Selim, S.; Alhammad, B.A.; Alharbi, B.M.; Juliatti, F.C. Will novel coronavirus (COVID-19) pandemic impact agriculture, food security and animal sectors? Biosci. J. 2020, 36. [CrossRef]

20. Ding, Z.; Ali, E.F.; Elmahdy, A.M.; Ragab, K.E.; Seleiman, M.F.; Kheir, A.M. Modeling the combined impacts of deficit irrigation, rising temperature and compost application on wheat yield and water productivity. Agric. Water Manag. 2021, $244,106626$. [CrossRef]

21. Fraser, E.; Legwegoh, A.; Kc, K.; CoDyre, M.; Dias, G.; Hazen, S.; Johnson, R.; Martin, R.; Ohberg, L.; Sethuratnam, S.; et al. Biotechnology or organic? Extensive or intensive? Global or local? A critical review of potential pathways to resolve the global food crisis. Trends Food Sci. Technol. 2016, 48, 78-87. [CrossRef]

22. Taha, R.S.; Seleiman, M.F.; Alotaibi, M.; Alhammad, B.A.; Rady, M.M.; HAMahdi, A. Exogenous potassium treatments elevate salt tolerance and performances of Glycine max L. by boosting antioxidant defense system under actual saline field conditions. Agronomy 2020, 10, 1741. [CrossRef]

23. Ma, Q.; Bao, A.-K.; Chai, W.-W.; Wang, W.-Y.; Zhang, J.; Li, Y.-X.; Wang, S.-M. Transcriptomic analysis of the succulent xerophyte Zygophyllum xanthoxylum in response to salt treatment and osmotic stress. Plant Soil 2016, 402, 343-361. [CrossRef]

24. Seleiman, M.F.; Semida, W.M.; Rady, M.M.; Mohamed, G.F.; Hemida, K.A.; Alhammad, B.A.; Hassan, M.M.; Shami, A. Sequential application of antioxidants rectifies ion imbalance and strengthens antioxidant systems in salt-stressed cucumber. Plants 2020, 9, 1783. [CrossRef]

25. Siddiqui, M.N.; Mostofa, M.G.; Akter, M.M.; Srivastava, A.K.; Sayed, M.A.; Hasan, M.S.; Tran, L.S.P. Impact of salt-induced toxicity on growth and yield-potential of local wheat cultivars: Oxidative stress and ion toxicity are among the major determinants of salt-tolerant capacity. Chemosphere 2017, 187, 385-394. [CrossRef]

26. Zaman, M.; Shahid, S.A.; Heng, L. Guideline for Salinity Assessment, Mitigation and Adaptation Using Nuclear and Related Techniques; Springer International Publishing: Berlin/Heidelberg, Germany, 2018.

27. Bagwasi, G.; Agenbag, G.A.; Swanepoel, P.A. Effect of salinity on the germination of wheat and barley in South Africa. Crop Forage Turfgrass Manag. 2020, 6, 20069. [CrossRef]

28. Miransari, M. Arbuscular Mycorrhizal Fungi and Soil Salinity. In Mycorrhizal Mediation of Soil; Elsevier: Amsterdam, The Netherlands, 2017; pp. 263-277.

29. Lokupitiya, E.; Agrawal, M.; Ahamed, T.; Mustafa, N.; Ahmed, B.; Vathani, A.; Opatha, K.; Jaiswal, B.; Singh, S.; Seneviratne, G.; et al. Evaluation of best management practices with greenhouse gas benefits for salt-affected paddy soils in South Asia APN Sci. Bull. 2020, 10. [CrossRef]

30. Zhao, C.; Zhang, H.; Song, C.; Zhu, J.-K.; Shabala, S. Mechanisms of Plant Responses and Adaptation to Soil Salinity. Innovation 2020, 1, 100017. [CrossRef] [PubMed]

31. Iqbal, M.J. Role of Osmolytes and Antioxidant Enzymes for Drought Tolerance in Wheat. Glob. Wheat Prod. 2018, 51. [CrossRef]

32. Seleiman, M.; Al-Suhaibani, N.; Ali, N.; Akmal, M.; Alotaibi, M.; Refay, Y.; Dindaroglu, T.; Abdul-Wajid, H.; Battaglia, M. Drought Stress Impacts on Plants and Different Approaches to Alleviate Its Adverse Effects. Plants 2021, 10, 259. [CrossRef] [PubMed]

33. Noctor, G.; Mhamdi, A.; Foyer, C.H. Oxidative stress and antioxidative systems: Recipes for successful data collection and interpretation. Plant Cell Environ. 2016, 39, 1140-1160. [CrossRef] [PubMed]

34. Hessini, K.; Ferchichi, S.; Ben Youssef, S.; Werner, K.H.; Cruz, C.; Gandour, M. How Does Salinity Duration Affect Growth and Productivity of Cultivated Barley? Agron. J. 2015, 107, 174-180. [CrossRef]

35. Debez, A.; Ben Slimen, I.D.; Bousselmi, S.; Atia, A.; Farhat, N.; El Kahoui, S.; Abdelly, C. Comparative analysis of salt impact on sea barley from semi-arid habitats in Tunisia and cultivated barley with special emphasis on reserve mobilization and stress recovery aptitude. Plant Biosyst. Int. J. Deal. Asp. Plant Biol. 2020, 154, 544-552. [CrossRef]

36. Mwando, E.; Han, Y.; Angessa, T.T.; Zhou, G.; Hill, C.B.; Zhang, X.-Q.; Li, C. Genome-Wide Association Study of Salinity Tolerance During Germination in Barley (Hordeum vulgare L.). Front. Plant Sci. 2020, 11, 118. [CrossRef] [PubMed]

37. Bilkis, A.; Islam, M.R.; Hafiz, M.H.R.; Hasan, M.A. Effect of $\mathrm{NaCl}$ induced salinity on some physiological and agronomic traits of wheat. Pak. J. Bot. 2016, 48, 455-460.

38. El-Hendawy, S.; Elshafei, A.; Al-Suhaibani, N.; Alotabi, M.; Hassan, W.; Dewir, Y.H.; Abdella, K. Assessment of the salt tolerance of wheat genotypes during the germination stage based on germination ability parameters and associated SSR markers. J. Plant Interact. 2019, 14, 151-163. [CrossRef]

39. Alom, R.; Hasan, A.; Islam, R.; Wang, Q.-F. Germination characters and early seedling growth of wheat (Triticum aestivum L.) genotypes under salt stress conditions. J. Crop. Sci. Biotechnol. 2016, 19, 383-392. [CrossRef] 
40. Desheva, G.; Desheva, G.N.; Stamatov, S.K. Germination and early seedling growth characteristics of Arachis hypogaea L. under Salinity (NaCl) Stress. Agric. Conspec. Sci. 2020, 85, 113-121.

41. Al-Shareef, N.O.; Tester, M. Plant Salinity Tolerance. In eLS; John Wiley \& Sons, Ltd.: Chichester, UK, 2019; pp. 1-6. [CrossRef]

42. Munns, R.; Guo, J.; Passioura, J.B.; Cramer, G.R. Leaf water status controls day-time but not daily rates of leaf expansion in salt-treated barley. Funct. Plant Biol. 2000, 27, 949-957. [CrossRef]

43. Fricke, W.; Akhiyarova, G.; Veselov, D.; Kudoyarova, G. Rapid and tissue-specific changes in ABA and in growth rate in response to salinity in barley leaves. J. Exp. Bot. 2004, 55, 1115-1123. [CrossRef] [PubMed]

44. Shabala, S.; Lew, R.R. Turgor Regulation in Osmotically Stressed Arabidopsis Epidermal Root Cells. Direct Support for the Role of Inorganic Ion Uptake as Revealed by Concurrent Flux and Cell Turgor Measurements. Plant Physiol. 2002, 129, 290-299. [CrossRef] [PubMed]

45. Wegner, L.; Stefano, G.; Shabala, L.; Rossi, M.; Mancuso, S.; Shabala, S. Sequential depolarization of root cortical and stelar cells induced by an acute salt shock-Implications for $\mathrm{Na}^{+}$and $\mathrm{K}^{+}$transport into xylem vessels. Plant Cell Environ. 2011, 34, 859-869. [CrossRef]

46. Christmann, A.; Grill, E.; Huang, J. Hydraulic signals in long-distance signaling. Curr. Opin. Plant Biol. 2013, 16, 293-300. [CrossRef] [PubMed]

47. Shabala, L.; Zhang, J.; Bacic, A.; Wu, H.; Azzarello, E.; Pandolfi, C.; Zhou, M.; Poschenrieder, C.; Mancuso, S.; Shabala, S.; et al. CellType-Specific $\mathrm{H}^{+}$-ATPase Activity in Root Tissues Enables $\mathrm{K}^{+}$Retention and Mediates Acclimation of Barley (Hordeum vulgare) to Salinity Stress. Plant Physiol. 2016, 172, 2445-2458. [CrossRef] [PubMed]

48. Cosgrove, D.; Hedrich, R. Stretch-activated chloride, potassium, and calcium channels coexisting in plasma membranes of guard cells of Vicia faba L. Planta 1991, 186, 143-153. [CrossRef] [PubMed]

49. Furuichi, T.; Tatsumi, H.; Sokabe, M. Mechano-sensitive channels regulate the stomatal aperture in Vicia faba. Biochem. Biophys. Res. Commun. 2008, 366, 758-762. [CrossRef]

50. Parkash, V.; Singh, S. Potential of Biochar Application to Mitigate Salinity Stress in Eggplant. HortScience 2020, 55, 1946-1955. [CrossRef]

51. $\mathrm{Wu}, \mathrm{H} . ;$ Zhang, X.; Giraldo, J.P.; Shabala, S. It is not all about sodium: Revealing tissue specificity and signalling roles of potassium in plant responses to salt stress. Plant Soil 2018, 431, 1-17. [CrossRef]

52. Benito, B.; Haro, R.; Amtmann, A.; Cuin, T.A.; Dreyer, I. The twins $\mathrm{K}^{+}$and $\mathrm{Na}^{+}$in plants. J. Plant Physiol. 2014, $171,723-731$. [CrossRef] [PubMed]

53. Cheeseman, J.M. The integration of activity in saline environments: Problems and perspectives. Funct. Plant Biol. 2013, 40, 759-774. [CrossRef] [PubMed]

54. Spitzer, J.; Poolman, B. The role of biomacromolecular crowding, ionic strength, and physicochemical gradients in the complexities of life's emergence. Microbiol. Mol. Biol. Rev. 2009, 73, 371-388. [CrossRef] [PubMed]

55. Grieve, C.M.; Grattan, S.R.; Maas, E.V. Plant Salt Tolerance. ASCE Man. Rep. Eng. Pract. 2012, 71, 405-459.

56. Munns, R.; James, R.A.; Läuchli, A. Approaches to increasing the salt tolerance of wheat and other cereals. J. Exp. Bot. 2006, 57, 1025-1043. [CrossRef] [PubMed]

57. Razzaq, A.; Ali, A.; Safdar, L.; Zafar, M.M.; Rui, Y.; Shakeel, A.; Shaukat, A.; Ashraf, M.; Gong, W.; Yuan, Y. Salt stress induces physiochemical alterations in rice grain composition and quality. J. Food Sci. 2020, 85, 14-20. [CrossRef] [PubMed]

58. Ibrahim, M.E.H.; Zhu, X.; Zhou, G.; Adam Ali, A.Y.; Ibrahim Elsiddig, A.M.; Farah, G.A. Response of Some Wheat Varieties to Gibberellic Acid under Saline Conditions. Agrosystems Geosci. Environ. 2019, 2, 1-7. [CrossRef]

59. Ibrahim, E.A. Seed priming to alleviate salinity stress in germinating seeds. J. Plant Physiol. 2016, 192, 38-46. [CrossRef] [PubMed]

60. Kumar, B.; Gangwar, V.; Parihar, S.K.S. Effect of saline water irrigation on germination and yield of wheat (Triticum aestivum L.) genotypes. Agrotechnology 2017, 6, 156.

61. Mohamed, A.K.S.H.; Qayyum, M.F.; Abdel-Hadi, A.M.; Rehman, R.A.; Ali, S.; Rizwan, M. Interactive effect of salinity and silver nanoparticles on photosynthetic and biochemical parameters of wheat. Arch. Agron. Soil Sci. 2017, 63, 1736-1747. [CrossRef]

62. Nimir, N.E.A.; Lu, S.; Zhou, G.; Guo, W.; Ma, B.; Wang, Y. Comparative effects of gibberellic acid, kinetin and salicylic acid on emergence, seedling growth and the antioxidant defence system of sweet sorghum (Sorghum bicolor) under salinity and temperature stresses. Crop. Pasture Sci. 2015, 66, 145-157. [CrossRef]

63. Calone, R.; Sanoubar, R.; Lambertini, C.; Speranza, M.; Antisari, L.V.; Vianello, G.; Barbanti, L. Salt Tolerance and Na Allocation in Sorghum bicolor under Variable Soil and Water Salinity. Plants 2020, 9, 561. [CrossRef]

64. Guimarães, M.J.M.; Simões, W.L.; De Oliveira, A.R.; De Araujo, G.G.; Silva, Ê.F.D.F.; Willadino, L.G. Biometrics and grain yield of sorghum varieties irrigated with salt water. Rev. Bras. Eng. Agrícola Ambient. 2019, 23, 285-290. [CrossRef]

65. Baghel, L.; Kataria, S.; Jain, M. Mitigation of adverse effects of salt stress on germination, growth, photosynthetic efficiency and yield in maize (Zea mays L.) through magnetopriming. Acta Agrobot. 2019, 72. [CrossRef]

66. Raza, M.M.; Ullah, S.; Aziz, T.; Abbas, T.; Yousaf, M.M.; Altay, V.; Ozturk, M. Alleviation of Salinity Stress in Maize Using Silicon Nutrition. Not. Bot. Horti Agrobot. Cluj-Napoca 2019, 47, 1340-1347. [CrossRef]

67. Tang, X.; Mu, X.; Shao, H.; Wang, H.; Brestic, M. Global plant-responding mechanisms to salt stress: Physiological and molecular levels and implications in biotechnology. Crit. Rev. Biotechnol. 2014, 35, 425-437. [CrossRef] [PubMed]

68. Hassan, N.; Hasan, K.; Shaddam, O.; Islam, M.S.; Barutçular, C.; El Sabagh, A. Responses of Maize Varieties to Salt Stress in Relation to Germination and Seedling Growth. Int. Lett. Nat. Sci. 2018, 69, 1-11. [CrossRef] 
69. AbdElgawad, H.; Zinta, G.; Hegab, M.M.; Pandey, R.; Asard, H.; Abuelsoud, W. High Salinity Induces Different Oxidative Stress and Antioxidant Responses in Maize Seedlings Organs. Front. Plant Sci. 2016, 7, 276. [CrossRef]

70. Iqbal, S.; Hussain, S.; Qayyaum, M.A.; Ashraf, M. The Response of Maize Physiology under Salinity Stress and Its Coping Strategies. In Plant Stress Physiology; Hossain, A., Ed.; IntechOpen Limited: London, UK, 2021.

71. Puvanitha, S.; Mahendran, S. Effect of salinity on plant height, shoot and root dry weight of selected rice cultivars. Sch. J. Agric. Vet. Sci. 2017, 4, 126-131.

72. Thu, T.T.P.; Yasui, H.; Yamakawa, T. Effects of salt stress on plant growth characteristics and mineral content in diverse rice genotypes. Soil Sci. Plant Nutr. 2017, 63, 1-10. [CrossRef]

73. Kongpun, A.; Jaisiri, P.; Rerkasem, B.; Prom-U-Thai, C. Impact of soil salinity on grain yield and aromatic compound in Thai Hom Mali rice cv. Khao Dawk Mali 105. Agric. Nat. Resour. 2020, 54, 74-78. [CrossRef]

74. Jamshidi, A.; Javanmard, H. Evaluation of barley (Hordeum vulgare L.) genotypes for salinity tolerance under field conditions using the stress indices. Ain Shams Eng. J. 2018, 9, 2093-2099. [CrossRef]

75. Habibi, G.; Aleyasin, Y. Green synthesis of Se nanoparticles and its effect on salt tolerance of barley plants. Int. J. Nano Dimens. 2020, 11, 145-157.

76. Zayed, M.M.; Elkafafi, S.H.; Zedan, A.M.G.; Dawoud, S.F.M. Effect of Nano Chitosan on Growth, Physiological and Biochemical Parameters of Phaseolus vulgaris under Salt Stress. J. Plant Prod. 2017, 8, 577-585. [CrossRef]

77. Zheng, C.; Zhou, G.; Zhang, Z.; Li, W.; Peng, Y.; Xie, X. Moderate Salinity Stress Reduces Rice Grain Yield by Influencing Expression of Grain Number- and Grain Filling-Associated Genes. J. Plant Growth Regul. 2021, 40, 1111-1120. [CrossRef]

78. Thitisaksakul, M.; Tananuwong, K.; Shoemaker, C.F.; Chun, A.; Tanadul, O.-U.-M.; Labavitch, J.M.; Beckles, D. Effects of Timing and Severity of Salinity Stress on Rice (Oryza sativa L.) Yield, Grain Composition, and Starch Functionality. J. Agric. Food Chem. 2015, 63, 2296-2304. [CrossRef]

79. Al-Ashkar, I.; Alderfasi, A.; El-Hendawy, S.; Al-Suhaibani, N.; El-Kafafi, S.; Seleiman, M.F. Detecting Salt Tolerance in Doubled Haploid Wheat Lines. Agronomy 2019, 9, 211. [CrossRef]

80. Li, J.; Chen, J.; Jin, J.; Wang, S.; Du, B. Effects of Irrigation Water Salinity on Maize (Zea may L.) Emergence, Growth, Yield, Quality, and Soil Salt. Water 2019, 11, 2095. [CrossRef]

81. Abbas, G.; Saqib, M.; Rafique, Q.; Rahman, A.U.; Akhtar, J.; Haq, M.A.U.; Nasim, M. Effect of salinity on grain yield and grain quality of wheat (Triticum aestivum L.). Pak J. Bot. 2013, 50, 185-189.

82. Yang, Y.; Guo, Y. Elucidating the molecular mechanisms mediating plant salt-stress responses. New Phytol. 2018, 217, 523-539. [CrossRef] [PubMed]

83. Pan, J.; Li, Z.; Dai, S.; Ding, H.; Wang, Q.; Li, X.; Ding, G.; Wang, P.; Guan, Y.; Liu, W. Integrative analyses of transcriptomics and metabolomics upon seed germination of foxtail millet in response to salinity. Sci. Rep. 2020, 10, 1-16. [CrossRef]

84. Julkowska, M.; Testerink, C. Tuning plant signaling and growth to survive salt. Trends Plant Sci. 2015, 20, 586-594. [CrossRef]

85. Genc, Y.; Oldach, K.; Taylor, J.; Lyons, G.H. Uncoupling of sodium and chloride to assist breeding for salinity tolerance in crops. New Phytol. 2016, 210, 145-156. [CrossRef] [PubMed]

86. Annunziata, M.G.; Ciarmiello, L.F.; Woodrow, P.; Dell'Aversana, E.; Carillo, P. Spatial and Temporal Profile of Glycine Betaine Accumulation in Plants Under Abiotic Stresses. Front. Plant Sci. 2019, 10, 230. [CrossRef] [PubMed]

87. Bhatt, T.; Sharma, A.; Puri, S.; Minhas, A.P. Salt Tolerance Mechanisms and Approaches: Future Scope of Halotolerant Genes and Rice Landraces. Rice Sci. 2020, 27, 368-383. [CrossRef]

88. Gupta, B.; Huang, B. Mechanism of Salinity Tolerance in Plants: Physiological, Biochemical, and Molecular Characterization. Int. J. Genom. 2014, 2014, 1-18. [CrossRef]

89. Parihar, P.; Singh, S.; Singh, R.; Singh, V.P.; Prasad, S.M. Effect of salinity stress on plants and its tolerance strategies: A review. Environ. Sci. Pollut. Res. 2015, 22, 4056-4075. [CrossRef]

90. Ismail, A.M.; Horie, T. Genomics, Physiology, and Molecular Breeding Approaches for Improving Salt Tolerance. Ann. Rev. Plant Biol. 2017, 68, 405-434. [CrossRef]

91. Munns, R.; Gilliham, M. Salinity tolerance of crops-what is the cost? New Phytol. 2015, 208, 668-673. [CrossRef] [PubMed]

92. Campbell, M.T.; Bandillo, N.; Al Shiblawi, F.R.A.; Sharma, S.; Liu, K.; Du, Q.; Schmitz, A.; Zhang, C.; Very, A.-A.; Lorenz, A.J.; et al. Allelic variants of OsHKT1;1 underlie the divergence between indica and japonica subspecies of rice (Oryza sativa) for root sodium content. PLoS Genet. 2017, 13, e1006823. [CrossRef] [PubMed]

93. Xu, B.; Waters, S.; Byrt, C.; Plett, D.; Tyerman, S.; Tester, M.; Munns, R.; Hrmova, M.; Gilliham, M. Structural variations in wheat HKT1;5 underpin differences in $\mathrm{Na}^{+}$transport capacity. Cell. Mol. Life Sci. 2018, 75, 1133-1144. [CrossRef] [PubMed]

94. Anirudh, K.V.S.; Chakraborty, T.; Srivastava, R.K.; Akhtar, N. Effect of Drought and Salt Stress on Cereal Crop Plants and their Proteomic and Physiological Studies. J. Biotechnol. Biomed. Sci. 2020, 2, 43-59. [CrossRef]

95. Ferchichi, S.; Hessini, K.; Dell'Aversana, E.; D'Amelia, L.; Woodrow, P.; Ciarmiello, L.F.; Fuggi, A.; Carillo, P. Hordeum vulgare and Hordeum maritimum respond to extended salinity stress displaying different temporal accumulation pattern of metabolites. Funct. Plant Biol. 2018, 45, 1096-1109. [CrossRef]

96. Byrt, C.; Munns, R.; Burton, R.; Gilliham, M.; Wege, S. Root cell wall solutions for crop plants in saline soils. Plant Sci. 2018, 269, 47-55. [CrossRef] [PubMed]

97. Geilfus, C.-M. The pH of the Apoplast: Dynamic Factor with Functional Impact Under Stress. Mol. Plant 2017, 10, 1371-1386. [CrossRef] 
98. Wakeel, A.; Sümer, A.; Hanstein, S.; Yan, F.; Schubert, S. In vitro effect of different Na+/K+ ratios on plasma membrane H+-ATPase activity in maize and sugar beet shoot. Plant Physiol. Biochem. 2011, 49, 341-345. [CrossRef] [PubMed]

99. Wahid, I.; Kumari, S.; Ahmad, R.; Hussain, S.; Alamri, S.; Siddiqui, M.; Khan, M. Silver Nanoparticle Regulates Salt Tolerance in Wheat Through Changes in ABA Concentration, Ion Homeostasis, and DefenseSystems. Biomolecules 2020, 10, 1506. [CrossRef] [PubMed]

100. Yang, Z.; Li, J.-L.; Liu, L.; Xie, Q.; Sui, N. Photosynthetic Regulation Under Salt Stress and Salt-Tolerance Mechanism of Sweet Sorghum. Front. Plant Sci. 2020, 10. [CrossRef] [PubMed]

101. Karami, A.; Sepehri, A. Nano titanium dioxide and nitric oxide alleviate salt induced changes in seedling growth, physiological and photosynthesis attributes of barley. Zemdirb. Agric. 2018, 105, 123-132. [CrossRef]

102. Al Kharusi, L.; Al Yahyai, R.; Yaish, M.W. Antioxidant Response to Salinity in Salt-Tolerant and Salt-Susceptible Cultivars of Date Palm. Agriculture 2019, 9, 8. [CrossRef]

103. Dolatabadian, A.; Sanavy, S.A.M.M.; Sharifi, M. Alleviation of Water Deficit Stress Effects by Foliar Application of Ascorbic Acid onZea maysL. J. Agron. Crop. Sci. 2009, 195, 347-355. [CrossRef]

104. Kaya, C.; Ashraf, M.; Sonmez, O.; Tuna, A.L.; Polat, T.; Aydemir, S. Exogenous application of thiamin promotes growth and antioxidative defense system at initial phases of development in salt-stressed plants of two maize cultivars differing in salinity tolerance. Acta Physiol. Plant. 2014, 37, 1741. [CrossRef]

105. Jaleel, C.A.; Manivannan, P.; Lakshmanan, G.M.A.; Sridharan, R.; Panneerselvam, R. NaCl as a physiological modulator of proline metabolism and antioxidant potential in Phyllanthus amarus. Comptes Rendus Biol. 2007, 330, 806-813. [CrossRef] [PubMed]

106. Del Río, L.A.; López-Huertas, E. ROS Generation in Peroxisomes and its Role in Cell Signaling. Plant Cell Physiol. 2016, 57, 1364-1376. [CrossRef]

107. Wingler, A.; Lea, P.J.; Quick, W.P.; Leegood, R.C. Photorespiration: Metabolic pathways and their role in stress protection. Philos. Trans. R. Soc. London. Ser. B Biol. Sci. 2000, 355, 1517-1529. [CrossRef]

108. Yu, Z.; Duan, X.; Luo, L.; Dai, S.; Ding, Z.; Xia, G. How Plant Hormones Mediate Salt Stress Responses. Trends Plant Sci. 2020, 25, 1117-1130. [CrossRef] [PubMed]

109. Ding, Y.; Liu, N.; Virlouvet, L.; Riethoven, J.-J.; Fromm, M.; Avramova, Z. Four distinct types of dehydration stress memory genes in Arabidopsis thaliana. BMC Plant Biol. 2013, 13, 229. [CrossRef] [PubMed]

110. Wang, J.; Song, L.; Gong, X.; Xu, J.; Li, M. Functions of Jasmonic Acid in Plant Regulation and Response to Abiotic Stress. Int. J. Mol. Sci. 2020, 21, 1446. [CrossRef] [PubMed]

111. Zhai, Y.; Wang, Y.; Li, Y.; Lei, T.; Yan, F.; Su, L.; Li, X.; Zhao, Y.; Sun, X.; Li, J.; et al. Isolation and molecular characterization of GmERF7, a soybean ethylene-response factor that increases salt stress tolerance in tobacco. Gene 2013, 513, 174-183. [CrossRef]

112. Fits, L.v.d.; Memelink, J. ORCA3, a Jasmonate-Responsive Transcriptional Regulator of Plant Primary and Secondary Metabolism. Science 2000, 289, 295-297. [CrossRef]

113. Cortleven, A.; Leuendorf, J.E.; Frank, M.; Pezzetta, D.; Bolt, S.; Schmülling, T. Cytokinin action in response to abiotic and biotic stresses in plants. Plant Cell Environ. 2019, 42, 998-1018. [CrossRef] [PubMed]

114. Ku, Y.-S.; Sintaha, M.; Cheung, M.-Y.; Lam, H.-M. Plant Hormone Signaling Crosstalks between Biotic and Abiotic Stress Responses. Int. J. Mol. Sci. 2018, 19, 3206. [CrossRef]

115. Cai, S.; Chen, G.; Wang, Y.; Huang, Y.; Marchant, D.B.; Wang, Y.; Yang, Q.; Dai, F.; Hills, A.; Franks, P.J.; et al. Evolutionary Conservation of ABA Signaling for Stomatal Closure. Plant Physiol. 2017, 174, 732-747. [CrossRef]

116. Přerostová, S.; Dobrev, P.I.; Gaudinova, A.; Hosek, P.; Soudek, P.; Knirsch, V.; Vankova, R. Hormonal dynamics during salt stress responses of salt-sensitive Arabidopsis thaliana and salt-tolerant Thellungiella salsuginea. Plant Sci. 2017, 264, 188-198. [CrossRef]

117. McAdam, S.A.M.; Sussmilch, F.; Brodribb, T. Stomatal responses to vapour pressure deficit are regulated by high speed gene expression in angiosperms. Plant Cell Environ. 2016, 39, 485-491. [CrossRef]

118. Zhao, Y.; Dong, W.; Zhang, N.; Ai, X.; Wang, M.; Huang, Z.; Xiao, L.; Xia, G. A Wheat Allene Oxide Cyclase Gene Enhances Salinity Tolerance via Jasmonate Signaling. Plant Physiol. 2014, 164, 1068-1076. [CrossRef] [PubMed]

119. Kurotani, K.-I.; Hayashi, K.; Hatanaka, S.; Toda, Y.; Ogawa, D.; Ichikawa, H.; Ishimaru, Y.; Tashita, R.; Suzuki, T.; Ueda, M.; et al. Elevated Levels of CYP94 Family Gene Expression Alleviate the Jasmonate Response and Enhance Salt Tolerance in Rice. Plant Cell Physiol. 2015, 56, 779-789. [CrossRef]

120. Prasad, R.; Bhattacharyya, A.; Nguyen, Q.D. Nanotechnology in Sustainable Agriculture: Recent Developments, Challenges, and Perspectives. Front. Microbiol. 2017, 8, 1014. [CrossRef] [PubMed]

121. Alabdallah, N.M.; Alzahrani, H.S. The potential mitigation effect of $\mathrm{ZnO}$ nanoparticles on [Abelmoschus esculentus L. Moench] metabolism under salt stress conditions. Saudi J. Biol. Sci. 2020, 27, 3132-3137. [CrossRef] [PubMed]

122. Hakeem, K.R.; Pirzadah, T.B. (Eds.) Nanobiotechnology in Agriculture: An Approach Towards Sustainability; Springer: Berlin/Heidelberg, Germany, 2020.

123. Martínez-Andújar, C.; Martínez-Pérez, A.; Ferrández-Ayela, A.; Albacete, A.; Martínez-Melgarejo, P.A.; Dodd, I.C.; Thompson, A.; Pérez-Pérez, J.M.; Pérez-Alfocea, F. Impact of overexpression of 9-cis-epoxycarotenoid dioxygenase on growth and gene expression under salinity stress. Plant Sci. 2020, 295, 110268. [CrossRef] [PubMed]

124. Miralles, P.; Church, T.L.; Harris, A.T. Toxicity, Uptake, and Translocation of Engineered Nanomaterials in Vascular plants. Environ. Sci. Technol. 2012, 46, 9224-9239. [CrossRef] 
125. Obroucheva, N.V.; Sinkevich, I.A.; Lityagina, S.V.; Novikova, G.V. Water relations in germinating seeds. Russ. J. Plant Physiol. 2017, 64, 625-633. [CrossRef]

126. Khodakovskaya, M.V.; De Silva, K.; Biris, A.S.; Dervishi, E.; Villagarcia, H. Carbon Nanotubes Induce Growth Enhancement of Tobacco Cells. ACS Nano 2012, 6, 2128-2135. [CrossRef]

127. Baz, H.; Creech, M.; Chen, J.; Gong, H.; Bradford, K.; Huo, H. Water-Soluble Carbon Nanoparticles Improve Seed Germination and Post-Germination Growth of Lettuce under Salinity Stress. Agronomy 2020, 10, 1192. [CrossRef]

128. Buzea, C.; Pacheco, I.I.; Robbie, K. Nanomaterials and nanoparticles: Sources and toxicity. Biointerphases 2007, 2, MR17-MR71. [CrossRef]

129. Pullagurala, V.L.R.; Adisa, I.O.; Rawat, S.; Kalagara, S.; Hernandez-Viezcas, J.A.; Peralta-Videa, J.R.; Gardea-Torresdey, J.L. ZnO nanoparticles increase photosynthetic pigments and decrease lipid peroxidation in soil grown cilantro (Coriandrum sativum). Plant Physiol. Biochem. 2018, 132, 120-127. [CrossRef]

130. Hezaveh, T.A.; Pourakbar, L.; Rahmani, F.; Alipour, H. Interactive Effects of Salinity and ZnO Nanoparticles on Physiological and Molecular Parameters of Rapeseed (Brassica napus L.). Commun. Soil Sci. Plant Anal. 2019, 50, 698-715. [CrossRef]

131. Arough, Y.K.; Sharifi, R.S.; Sedghi, M.; Barmaki, M. Effect of Zinc and Bio Fertilizers on Antioxidant Enzymes Activity, Chlorophyll Content, Soluble Sugars and Proline in Triticale Under Salinity Condition. Not. Bot. Horti Agrobot. Cluj-Napoca 2016, 44, 116-124. [CrossRef]

132. Babaei, K.; Sharifi, R.S.; Pirzad, A.; Khalilzadeh, R. Effects of bio fertilizer and nano Zn-Fe oxide on physiological traits, antioxidant enzymes activity and yield of wheat (Triticum aestivum L.) under salinity stress. J. Plant Interact. 2017, 12, 381-389. [CrossRef]

133. Acosta-Motos, J.R.; Ortuño, M.F.; Bernal-Vicente, A.; Diaz-Vivancos, P.; Sanchez-Blanco, M.J.; Hernandez, J.A. Plant Responses to Salt Stress: Adaptive Mechanisms. Agronomy 2017, 7, 18. [CrossRef]

134. Seleiman, M.F.; Kheir, A.M. Maize productivity, heavy metals uptake and their availability in contaminated clay and sandy alkaline soils as affected by inorganic and organic amendments. Chemosphere 2018, 204, 514-522. [CrossRef] [PubMed]

135. Betzen, B.M.; Smart, C.M.; Maricle, K.L.; Maricle, B.R. Effects of Increasing Salinity on Photosynthesis and Plant Water Potential in Kansas Salt Marsh Species. Trans. Kans. Acad. Sci. 2019, 122, 49. [CrossRef]

136. Asada, K. Production and Scavenging of Reactive Oxygen Species in Chloroplasts and Their Functions. Plant Physiol. 2006, 141, 391-396. [CrossRef]

137. Li, H.; Wen, Y.; Wang, J.; Sun, B. The molecular structures of leached starch during rice cooking are controlled by thermodynamic effects, rather than kinetic effects. Food Hydrocoll. 2017, 73, 295-299. [CrossRef]

138. Wang, H.; Shabala, L.; Zhou, M.; Shabala, S. Hydrogen Peroxide-Induced Root $\mathrm{Ca}^{2+}$ and $\mathrm{K}^{+}$Fluxes Correlate with Salt Tolerance in Cereals: Towards the Cell-Based Phenotyping. Int. J. Mol. Sci. 2018, 19, 702. [CrossRef]

139. Çiçek, N.; Oukarroum, A.; Strasser, R.J.; Schansker, G. Salt stress effects on the photosynthetic electron transport chain in two chickpea lines differing in their salt stress tolerance. Photosynth. Res. 2018, 136, 291-301. [CrossRef] [PubMed]

140. Suo, J.; Zhao, Q.; David, L.; Chen, S.; Dai, S. Salinity Response in Chloroplasts: Insights from Gene Characterization. Int. J. Mol. Sci. 2017, 18, 1011. [CrossRef]

141. Kalteh, M.; Alipour, Z.T.; Ashraf, S.; Aliabadi, M.M.; Nosratabadi, A.F. Effect of silica Nanoparticles on Basil (Ocimum basilicum) Under Salinity Stress. J. Chem. Health Risks 2014, 4. [CrossRef]

142. Zhang, J.; Wei, J.; Li, D.; Kong, X.; Rengel, Z.; Chen, L.; Yang, Y.; Cui, X.; Chen, Q. The Role of the Plasma Membrane H+-ATPase in Plant Responses to Aluminum Toxicity. Front. Plant Sci. 2017, 8, 1757. [CrossRef] [PubMed]

143. Kataria, S.; Jain, M.; Rastogi, A.; Živčák, M.; Brestic, M.; Liu, S.; Tripathi, D.K. Role of Nanoparticles on Photosynthesis: Avenues and Applications, in Nanomaterials in Plants, Algae and Microorganisms; Elsevier: Amsterdam, The Netherlands, $2019 ;$ pp. $103-127$.

144. Seleiman, M.F.; Alotaibi, M.A.; Alhammad, B.A.; Alharbi, B.M.; Refay, Y.; Badawy, S.A. Effects of ZnO Nanoparticles and Biochar of Rice Straw and Cow Manure on Characteristics of Contaminated Soil and Sunflower Productivity, Oil Quality, and Heavy Metals Uptake. Agronomy 2020, 10, 790. [CrossRef]

145. Queiroz, A.; Mezacasa, A.; Graciano, D.; Falco, W.; M’Peko, J.-C.; Guimarães, F.; Lawson, T.; Colbeck, I.; Oliveira, S.; Caires, A. Quenching of chlorophyll fluorescence induced by silver nanoparticles. Spectrochim. Acta Part A Mol. Biomol. Spectrosc. 2016, 168, 73-77. [CrossRef] [PubMed]

146. Fathi, A.; Zahedi, M.; Torabian, S. Effect of interaction between salinity and nanoparticles (Fe2O3and ZnO) on physiological parameters ofZea maysL. J. Plant Nutr. 2017, 40, 2745-2755. [CrossRef]

147. Ye, Y.; Medina-Velo, I.A.; Cota-Ruiz, K.; Moreno-Olivas, F.; Gardea-Torresdey, J.L. Can abiotic stresses in plants be alleviated by manganese nanoparticles or compounds? Ecotoxicol. Environ. Saf. 2019, 184, 109671. [CrossRef]

148. Pavithra, G.J.; Reddy, B.H.R.; Salimath, M.; Geetha, K.N.; Shankar, A.G. Zinc oxide nano particles increases Zn uptake, translocation in rice with positive effect on growth, yield and moisture stress tolerance. Indian J. Plant Physiol. 2017, 22, $287-294$. [CrossRef]

149. Bello, S.K.; Alayafi, A.H.; Al-Solaimani, S.G.; Abo-Elyousr, K.A.M. Mitigating Soil Salinity Stress with Gypsum and Bio-Organic Amendments: A Review. Agronomy 2021, 11, 1735. [CrossRef]

150. Wu, H.-J.; Zhang, Z.; Wang, J.; Oh, D.-H.; Dassanayake, M.; Liu, B.; Huang, Q.; Sun, H.-X.; Xia, R.; Wu, Y.; et al. Insights into salt tolerance from the genome ofThellungiella salsuginea. Proc. Natl. Acad. Sci. USA 2012, 109, 12219-12224. [CrossRef] [PubMed]

151. Barlow, B. Leaching Kinetics of Carbonatite and Silicate Based Chalcopyrite Minerals. Ph.D. Thesis, North-West University, Potchefstroom, South Africa, 2020. 
152. Vejan, P.; Khadiran, T.; Abdullah, R.; Ahmad, N. Controlled release fertilizer: A review on developments, applications and potential in agriculture. J. Control. Release 2021, 339, 321-334. [CrossRef] [PubMed]

153. Machado, R.; Serralheiro, R. Salt stress alleviation through fertilization in fruit crops. In Fruit Crops; Elsevier BV: Amsterdam, The Netherlands, 2020; pp. 465-480.

154. Cuevas, J.; Daliakopoulos, I.N.; Del Moral, F.; Hueso, J.J.; Tsanis, I.K. A Review of Soil-Improving Cropping Systems for Soil Salinization. Agronomy 2019, 9, 295. [CrossRef]

155. Seleiman, M.F.; Aslam, M.T.; Alhammad, B.A.; Hassan, M.U.; Maqbool, R.; Chattha, M.U.; Khan, I.; Gitari, H.I.; Uslu, O.S.; Roy, R.; et al. Salinity stress in wheat: Effects, mechanisms and management strategies. Phyton Int. J. Exp. Bot. 2021. [CrossRef]

156. Badawy, S.A.; Zayed, B.A.; Bassiouni, S.M.A.; Mahdi, A.H.A.; Majrashi, A.; Ali, E.F.; Seleiman, M.F. Influence of Nano Silicon and Nano Selenium on Root Characters, Growth, Ion Selectivity, Yield, and Yield Components of Rice (Oryza sativa L.) under Salinity Conditions. Plants 2021, 10, 1657. [CrossRef]

157. Seleiman, M. Use of plant nutrients in improving abiotic stress tolerance in wheat. In Wheat Production in Changing Environments; Hasanuzzaman, M., Nahar, K., Hossain, M.A., Eds.; Springer: Singapore, 2019; pp. 481-495.

158. Aragüés, R.; Medina, E.; Clavería, I.; Martínez-Cob, A.; Faci, J. Regulated deficit irrigation, soil salinization and soil sodification in a table grape vineyard drip-irrigated with moderately saline waters. Agric. Water Manag. 2014, 134, 84-93. [CrossRef]

159. Gabriel, J.L.; Vanclooster, M.; Quemada, M. Integrating Water, Nitrogen, and Salinity in Sustainable Irrigated Systems: Cover Crops versus Fallow. J. Irrig. Drain. Eng. 2014, 140, A4014002. [CrossRef]

160. Sharma, P.K.; Bhagat, R.M. Puddling and compaction effects on water permeability of texturally different soils. J. Indian Soc. Soil Sci. 1993, 41, 1-6.

161. Colla, G.; Rouphael, Y.; Leonardi, C.; Bie, Z. Role of grafting in vegetable crops grown under saline conditions. Sci. Hortic. 2010, 127, 147-155. [CrossRef]

162. Seleiman, M.F.; Santanen, A.; Kleemola, J.; Stoddard, F.L.; Mäkelä, P.S. Improved sustainability of feedstock production with sludge and interacting mycorrhiza. Chemosphere 2013, 91, 1236-1242. [CrossRef]

163. Evelin, H.; Devi, T.S.; Gupta, S.; Kapoor, R. Mitigation of Salinity Stress in Plants by Arbuscular Mycorrhizal Symbiosis: Current Understanding and New Challenges. Front. Plant Sci. 2019, 10, 470. [CrossRef] [PubMed]

164. Ilangumaran, G.; Smith, D.L. Plant Growth Promoting Rhizobacteria in Amelioration of Salinity Stress: A Systems Biology Perspective. Front. Plant Sci. 2017, 8, 1768. [CrossRef] [PubMed] 